\title{
The invertebrate fauna of the Middle Miocene (Lower Badenian) sediments of Kralice nad Oslavou (Central Paratethys, Moravian part of the Carpathian Foredeep)
}

\author{
KAMIL ZÁGORŠEK, KATARÍNA HOLCOVÁ, SLAVOMÍR NEHYBA, ANDREAS KROH \& ŠÁRKA \\ HLADILOVÁ
}

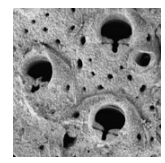

\begin{abstract}
An artificial outcrop of Middle Miocene sediments at Kralice nad Oslavou has been studied in detail, all fragments retrieved from the bulk samples were evaluated and described. The most common fossils were bryozoans, foraminifers and echinoderms, but molluscs also occured. Foraminiferal evidence indicates an assignment to the lower part of the Upper Lagenid Zone (Lower Badenian-Langhian, Middle Miocene); the calcareous nannoplankton is characteristic for the zone NN5. In the upper part of the profile, an increased amount of volcanic material can be recognised. Based on an analysis of the faunal composition, the palaeoenvironmental evolution of the section has been investigated. The sediments at the base of the section originate from a deeper marine basin and well oxygenated bottom waters. A first bryozoan event can be recorded in this interval. Above, foraminiferal evidence points to increased depth and decreased oxygen levels, coinciding with an abundance peak of molluscs and asteroids, but disappearance of bryozoans. In the upper half of the section, conditions changed considerably. The faunal content indicates a shallow-marine environment with normal marine salinity and high oxygen levels. Echinoderms and bryozoans exhibit high diversities in this interval. These drastic changes are related here to changes in basin geometry. Increased volcanic activity in the hinterland was documented by volcano-detritic material in the sediment. Neotypes of bryozoans Kionidella moravicensis Procházka, 1893 and Umbonula spinosa (Procházka, 1893) are designated. - Key words: Bryozoa, Foraminifera, Echinodermata, Mollusca, palaeoecology, Middle Miocene, Carpathian Foredeep, Czech Republic.
\end{abstract}

ZÁGORŠEK, K., HolcovÁ, K., NehYBA, S., KROH, A. \& HladilovÁ, Š. 2008. The invertebrate fauna of the Middle Miocene (Lower Badenian) sediments of Kralice nad Oslavou (Central Paratethys, Moravian part of the Carpathian Foredeep). Bulletin of Geosciences 84(3), 465-496 (13 figures). Czech Geological Survey, Prague. ISSN 1214-1119. Manuscript received May 7, 2008; accepted in revised form November 10, 2008; published online August 14, 2009; issued September 11, 2009.

Kamil Zágoršek, Department of Palaeontology, National Museum, Václavské náměstí 68, CZ-115 74 Praha 1, Czech Republic; kamil.zagorsek@nm.cz • Katarína Holcová, Institute of Geology \& Palaeontology, Charles University in Prague, Albertov 6, CZ-12843 Praha 2; holcova@natur.cuni.cz• Slavomír Nehyba, Institute of Geological Sciences, Masaryk University, Kotlářská 2, 61137 Brno, Czech Republic; slavek@sci.muni.cz• Andreas Kroh, Natural History Museum Vienna, Department of Geology \& Palaeontology, Burgring 7, 1010 Wien, Austria; andreas.kroh@nhm-wien.ac.at • Śárka Hladilová, Department of Biology, Faculty of Education, Palacký University, Purkrabská 2, 77146 Olomouc, Czech Republic; sarka.hladilova@upol.cz

Erosional relicts of marine Neogene deposits located on the crystalline rocks of the SW margin of the Bohemian Massif reveal evidence about the actual extent of the Carpathian Foredeep but also about post-depositional processes of uplift and erosion. Correlation of these deposits with the internal part of the basin is important for the detailed sequence stratigraphy of the Foredeep.

These deposits of Early Badenian age were studied in the vicinity of Kralice nad Oslavou. The section Kralice nad Oslavou was first described by Procházka (1893). It was later studied by Janoschek (1937), Koutek (1971), Hamršmíd (1984), Hladíková \& Hamršmíd (1986), Redinger (1990) and
Hladilová et al. (1999). Terrestrial Neogene deposits around Kralice nad Oslavou were investigated by Brzák et al. (2001), and Nehyba (2003). Kralice nad Oslavou is well known for its massive occurrence of Bryozoa (Procházka 1893), interpreted later as the Early Badenian bryozoan event (Zágoršek \& Holcová 2003). The bryozoan fauna has been revised by Sváček (1995). Hamršmíd (1981, 1984) studied the foraminifers and interpreted the strata outcropping at Kralice as normal marine deposits, located at some distance from the ancient shoreline. He estimated a palaeo-depth of sixty to ninety metres, with a regression in the uppermost part of the succession. Brzobohatý $(1997,2001)$ estimated a maximum 

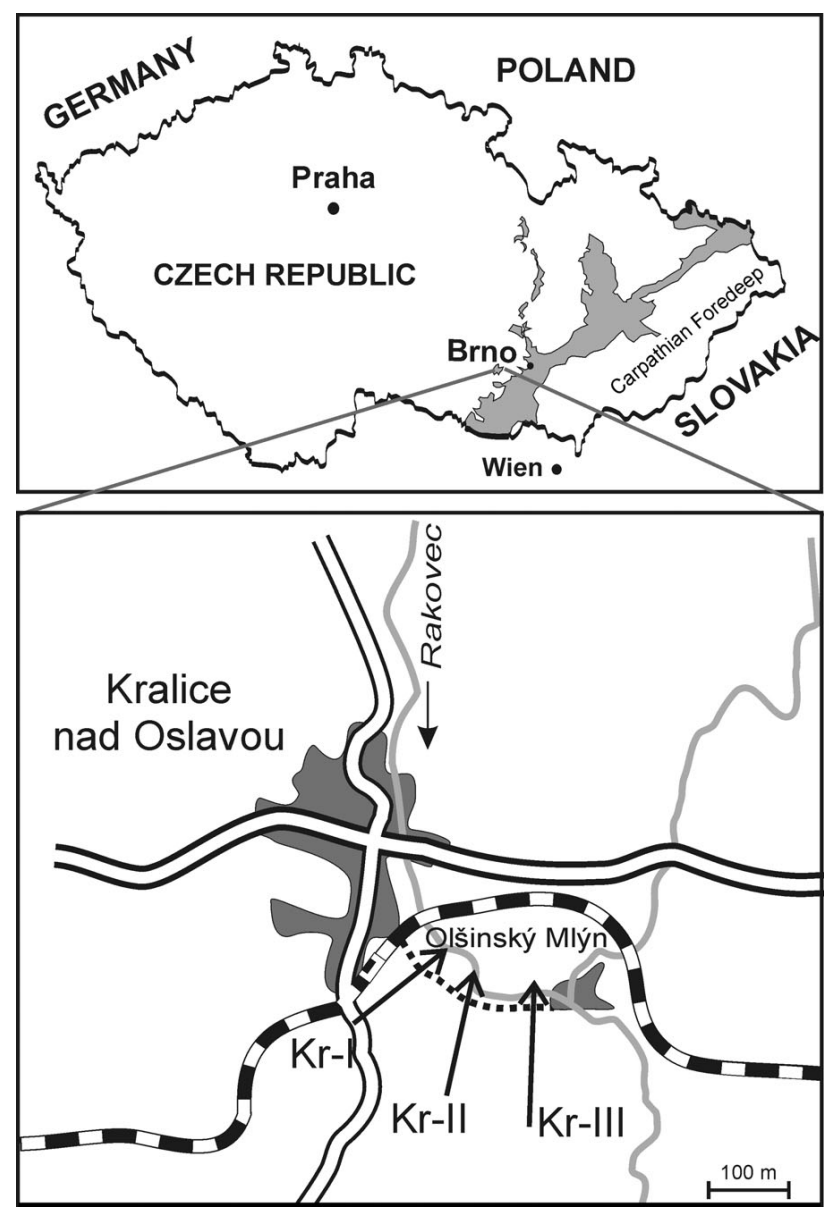

Figure 1. Geographical sketch of the sections around Kralice (Kr), Czech Republic.

palaeodepth of $100 \mathrm{~m}$ based on the otolith associations from the Hamršmíd locality. Redinger (1990) described a new species of Bolboformacea Bolboforma moravica from this locality. The co-occurrence of this species with $B$. reticulata is indicative for the Lower Badenian age.

During last four years we investigated 52 localities in the Moravian part of the Carpathian Foredeep. At Kralice nad Oslavou three outcrops could be located (Fig. 1), situated on the left bank of the Rakovec creek (former Jinošov creek), which might correspond to the classic locality of Procházka (1893). The outcrop Kralice-I (49 $11.619^{\prime} \mathrm{N}, 016^{\circ}$ $\left.12.493^{\circ} \mathrm{E}\right)$ exposes greyish claystone and did not yield any fossils so far. The second outcrop, Kralice-II, (49 $11.591^{\prime} \mathrm{N}$, $\left.016^{\circ} 12.516^{\prime} \mathrm{E}\right)$ contains mainly foraminifera in a yellowish sandstone. This profile has been studied in detail by Zágoršek et al. (2007a). The third section, Kralice-III (49 $9^{\circ} 11.584^{\prime} \mathrm{N}$, $016^{\circ} 12.538^{\prime} \mathrm{E}$ ), is rich in shallow water bryozoans (studied by Zágoršek), foraminifers (studied by Holcová) as well as in molluscs (studied by Hladilová) and echinoderms (studied by Kroh) in a yellow marl to calcareous sandstone (sedimentology studied by Nehyba) and is the subject of the present paper.
Although this cannot be demonstrated with $100 \%$ certainty, we consider Kralice-III to be identical with the locality "Kralice" of Procházka (1893), Hamršmíd (1984) and Sváček (1995). The section Kralice-III was logged by Třasoň (2005). Altogether, we collected 12 samples (KRAS-1 to 12) from the section. The detailed study of these samples is presented here.

\section{Methods}

Foraminifera, Bryozoa, Echinodermata and Mollusca were collected from $63 \mu \mathrm{m}-2 \mathrm{~mm}$ fractions after washing disintegrated rock samples in water. Washed residues were teased apart under a stereo microscope. Ultrasonic treatment and hydrogen peroxide was used for further cleaning before photographing.

Grain size was evaluated by combined sieving and laser diffraction methods to cover a wide size spectra. A Retch AS 200 sieving machine covered the coarser grain fractions (63 $\mu \mathrm{m}-4 \mathrm{~mm})$, whereas a Cilas 1064 laser diffraction granulometer was used for the finer ones $(0.4-500 \mu \mathrm{m})$. Ultrasonic dispersion and distilled water were used prior to analyses in order to avoid flocculation of particles. Sorting $\sigma$ I was counted according to the formula of Folk \& Ward (1957). Petrography of the coarse grained fraction (13 analyses) was studied under microscope in the fraction coarser than $4 \mathrm{~mm}$. Associations of transparent heavy minerals (13 analyses) were evaluated in the grain size fraction $0.063-0.125 \mathrm{~mm}$. Chemistry of garnet (23 analyses) and rutile (15 analyses) were studied using a microprobe analyser Cameca SX-100.

About 200-300 specimens of Foraminifera from each sample were determined (Appendix A) and relative abundances of taxa were calculated.

Slides for calcareous nannoplankton study were prepared by the following technique: approximately $0.5 \mathrm{cc}$ of rock sample was pulverized and diluted in $5 \mathrm{ml}$ of water. One minute after shaking, one drop of suspension from the middle of the water column was dripped onto a microscopic slide. After drying, standard microscope slides were prepared which were then analysed using a light microscope (normal and crossed nicols, $1000 \times$ magnification). About 200-500 specimens of calcareous nannoplankton were determined from individual samples (Appendix B) and relative abundances of taxa were calculated.

Bryozoans were studied and documented using a Jeol type JSM-6400 SEM; all measurements were made by SemAfore ${ }^{\circledR} 3.0$ pro Jeol software in the Department of Palaeontology (Vienna University). Specimens of bryozoans described here are deposited in the National Museum in Prague, specimens of molluscs are deposited in Masaryk University Brno and echinoids samples are stored in NHM Vienna. 
Palaeoecological analysis was based on the following data: (1) Shell preservation and comparison of stratigraphical ranges of taxa in assemblages which were used to indicate taphonomical processes: (i) Size-sorting of foraminiferal tests, their corrosion and abrasion as well as damage and abrasion of bryozoan colonies and molluscs can indicate bedload transport (Davies et al. 1989, Kidwell 1986, Kidwell \& Bosence 1991, Murray 1991, Holcová 1996). (ii) Oscillations in relative abundances of reworked taxa in thanatocenosis (reworked taxa were determined from their different stratigraphical ranges in comparison with autochtonous taxa) give information about re-deposition and occurrence of sedimentary rocks in the source area of clasts including coccoliths.

(2) Absolute abundance of fossil groups in sediment indicating changes of productivity as well as oscillations in input of terrigenous material: (i) Foraminiferal number number of foraminiferal tests in one gram dry weight of sediment. (ii) Calcareous nannoplankton: Abundance of nannoplankton was expressed here as a number of specimens in a microscope field of view $(1000 \times$ magnification $)$. The number of nannoplankton specimens in the field of view was counted for twenty fields and mean, maximal and minimal values were summarized in a graph. (iii) Molluscs and Rhodophyta were evaluated semi-quantitatively from $100 \mathrm{~g}$ dry weight of sediment: less than 5 fragments were classed as "rare", 6-15 fragments as "common", 16-35 fragments as "abundant", 36-60 fragments as "very abundant" and more than 60 fragments as "dominant". (iv) Bryozoan fragments were also evaluated on a semi-quantitative scale from the $100 \mathrm{~g}$ dry weight of sediment: less than 5 fragments were classed as "rare", 6-10 fragments as "common", 11-20 fragments as "abundant", 21-40 fragments as "very abundant" and more than 40 fragments as "dominant". Number of bryozoan fragments reflects the abundance of bryozoan clasts among other bioclasts and rock pieces in the washed residuum and does not express the number of animals or colonies. (v) The complete set of echinoderm fragments collected from the samples were determined and counted.

Note that quantitative and also semi-quantitative data obtained from molluscs, bryozoans and echinoderms do not refer to the number of individuals. We can, however, use these values to estimate biomass produced by particular groups of animals and compare this value with other groups.

(3) Diversities of analysed groups were expressed as numbers of species in assemblages, calculated separately for benthic, planktonic foraminifera, bryozoans, calcareous nannoplankton, molluscs and echinoderms.

(4) Relative abundance of palaeoenvironmental markers: (i) Relative abundances of euryhaline species (Ammonia spp., Elphidium spp., miliolids; Murray 1991), their abundant occurrence can indicate oscillations of salinity. (ii) Relative abundances of high primary productivity markers among benthic species (U. grilli, U. macrocarinata, U. pygmoides, U. uniseriata, M. pompiloides; Spezzaferri et al. 2002) which reflect oscillations of primary productivity at the bottom. (iii) Relative abundances of oxiphylic species (Kaiho 1994, Kaiho 1999, den Dulk et al. 1998, den Dulk et al. 2000, Spezzaferri et al. 2002 and Báldi 2006). (iv) Relative abundances of passive suspension feeder, herbivore and detrivore benthic foraminifera (Murray 1991) were used for interpretation of available sources of food. (v) Relative abundance of epifaunal species which indicate seagrass meadows. (vi) Relative abundances of Thoracosphaera spp. in calcareous nannoplankton assemblages. Increasing abundance can indicate a deterioration in the environment of the nannoplankton.

(5) Indexes: (i) Oxygen contents were estimated using BFOI = Benthic Foraminiferal Oxygen Index (Kaiho 1994, 1999): $\mathrm{BFOI}=\mathrm{O} /(\mathrm{O}+\mathrm{D}) * 100$, where $\mathrm{O}$ is number of oxic indicators and $\mathrm{D}$ is number of dysoxic indicators. Oxic and dysoxic indicators were classified according to Kaiho (1994, 1999), den Dulk et al. (1998), den Dulk et al. (2000), Spezzaferri et al. (2002) and Báldi (2006). (ii) Palaeodepth was estimated using the relationship between bathymetry and relative abundance of planktonic foraminifera as determined by van der Zwaan et al. (1990). This depth relationship between abundance of planktonic and benthic foraminifera is based on the fact that the availability of nutrients on the sea floor depends on depth. Depth $[\mathrm{m}]=\mathrm{e} 3.58718+(0.03534 \times \mathrm{Pc})$, where D is estimated depth in meters, $\mathrm{Pc}$ is corrected ratio of planktonic/ benthic foraminifera: $\mathrm{Pc}=(\mathrm{P} \times 100) /[\mathrm{P}+(\mathrm{Bt}-\mathrm{Bi})]$, where $\mathrm{P}$ is the number of planktonic foraminifera, $\mathrm{Bt}$ is total number of benthic foraminifera and $\mathrm{Bi}$ is the number of deep infaunal species (van der Zwaan et al. 1990, van Hinsbergen et al. 2005, Báldi 2006) which are excluded from analysis because they are not directly dependent on the flux of organic matter to the sea floor. The P/B-ratio is not only influenced by depth, but also by changes in oxygenation of bottom waters (Sen-Gupta \& Machain-Castillo 1993, Jorissen et al. 1995) which may fluctuate (Kouwenhoven et al. 2003). Research on deposits from epicontinental basins like the Paratethys showed that the calculated palaeodepth may overestimate depth of deposition (Spezzaferri et al. 2002, 2004; Hohenegger 2005) and faunal composition of foraminiferal assemblages is thus more important for palaeodepth estimations in these basins.

\section{Results}

\section{Facies study}

Subhorizontal bedding was followed within the profile. Individual beds generally have a massive character and are usually not well separated from overlying/underlying beds. 


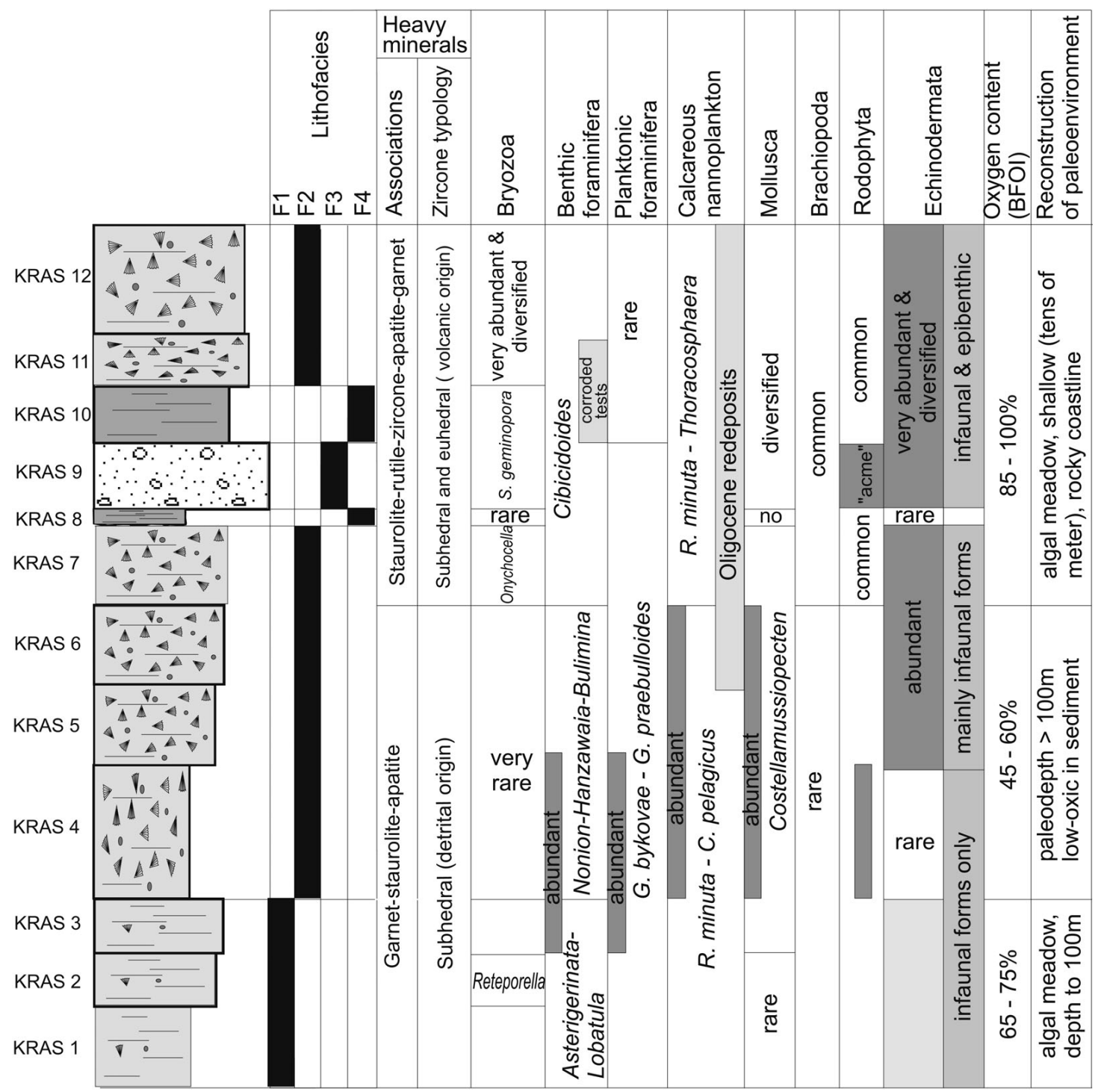

Figure 2. Lithostratigraphic $\log$ of the studied section with indication of faunal changes and facies. Facies type F1: poorly sorted calcareous sandy silt or fine sand. Facies type F2: poorly sorted very fine calcareous silty sand with abundant shells or shells debris. Facies type F3: poorly sorted sand with angular psefitic clasts. Facies type F4: poorly sorted calcareous mudstone to muddy limestone. Detailed description contained in text.

Four lithofacies were recognised based on differences in the grain size, content of pebbles and shell fragments (Figs 2,3).

F1 (samples KRAS-1-3): Light grey-green or yellowgreen yellowish mottled calcareous sandy silt or silty very fine to fine sand, rare whitish calcareous concretions up to 5 $\mathrm{cm}$ in diameter. Very low amount of shell debris. Sediment is very poorly sorted ( $\sigma$ I varies between 4.07 and 4.26).

F2 (samples KRAS-4-7, 11, 12): Light grey-green, brownish or whitish yellow, calcareous very fine to fine silty sand, rarely sandy silt, with abundant shells or shells debris. Presence of intraclasts (max. $\varnothing 2 \mathrm{~cm}$ ) or discontinuous laminas of dark grey or green-grey mudstone are rare. Whitish calcareous concretions were sometimes observed. Stratification is poorly visible. Sediment is very poorly sorted ( $\sigma$ I varies between 2.64 and 4.2).
F3 (sample KRAS-9): Yellow-brown poorly sorted sand with angular clasts up to $20 \mathrm{~cm}$ in diameter. Irregular intraclasts of sandy clays or clayey sand (up to $5 \mathrm{~cm}$ in diameter) originating from the lower bed (facies F4) and shell debris are all present. Sediment is very poorly sorted ( $\sigma \mathrm{I}$ is 3,17$)$.

F4 (samples KRAS-8 and 10): Whitish green-grey calcareous mudstone to muddy limestone. Sediment is very poorly sorted ( $\sigma$ I varies between 2.99 and 3.07).

\section{Sedimentary petrography}

Psefitic fraction is represented exclusively by shell debris in samples KRAS-1 to 8, 10 and 12 (facies F1, 2, 4). In samples KRAS-9, 11 shell debris is also dominating within 
the psefitic fraction but extraclasts were also recognised. They are formed by subangular to subrounded, subdiscoidal or spherical clasts of whitish/milky quartz, quartzites or gneisses. Their size varies from $4 \mathrm{~mm}$ up to $20 \mathrm{~cm}$ (A axis). The largest one is formed by muscovite-biotite gneiss identical with the local bedrock (Mísař et al. 1993).

Variations in the association of the transparent heavy mineral spectra were recognised within the profile. Garnet-staurolite-apatite associations dominate in the lower part of the profile (samples KRAS-1 to 6). Other heavy minerals (tourmaline, zircone, rutile, monazite, zoisit-epidote, amphibole, kyanite, pyroxene, andalusite, sillimanite and titanite) occurred as a few percent at the most. The ZTR index (zircon-tourmaline-rutile; Hubert 1962, Morton \& Hallsworth 1994) varies between 10.9 and $29.3 \%$. Usually tourmaline or zircone are the dominant stable minerals. This can be explained by the higher role of first cycle detritus and the dominant provenance from low-grade metamorphic rocks. A staurolite-rutile-zircone-apatite and garnet association is typical for the upper part (samples KRAS-7 to 12) of the profile. The occurrence of other minerals (tourmaline, monazite, zoisit-epidote, amphibole, kyanite, pyroxene, andalusite, sillimanite and titanite) is restricted to low amounts of only a few percent. The value of the ZTR index lies between 37.2 and 50.7\%. Zircon and rutile dominate within the stable minerals whereas tourmaline is less common. This can be explained by the provenance from both magmatic and metamorphic rocks. Redeposition from older deposits cannot be completely ruled out, but further zircon studies suggest a volcanic origin for part of the clastic material.

Zircons observed in the studied samples from the upper part of the profile (samples KRAS-7 to 12) had a euhedral shape. Such a shape is often considered to indicate first-cycle detritus (no previous depositional history) and evidence of magmatic or volcanic origin (Poldervaart 1950, Lihou \& Mange-Rajetzky 1996). In this case, zircons were suitable for using zircon typology (Pupin 1980, 1985) evaluation. This method was used in Neogene volcaniclastics as an effective tool for their correlation (Nehyba 1997, Nehyba \& Roetzel 1999, Nehyba \& Stráník 2005). Typological distribution of the zircon population is based on the study of 85 grains from samples KRAS-7 to 12 . The majority of the studied zircons $(61.4 \%)$ correspond to the subtypes P1, P2and P3. Similar zircons are the dominant volcanic zircons reported from Lower Badenian deposits of the Carpathian Foredeep (Nehyba 1997). Zircon shape gives additional evidence for a volcanic provenance. Zircons with elongation values greater than 3 were relatively common in the studied zircon spectra. Such zircon shapes are generally supposed to reflect magmatic/volcanic origin (Zimmerle 1979) and/or limited transport. Moreover, the abundant occurrence of biotite was recognised within the upper part of the profile (especially in samples

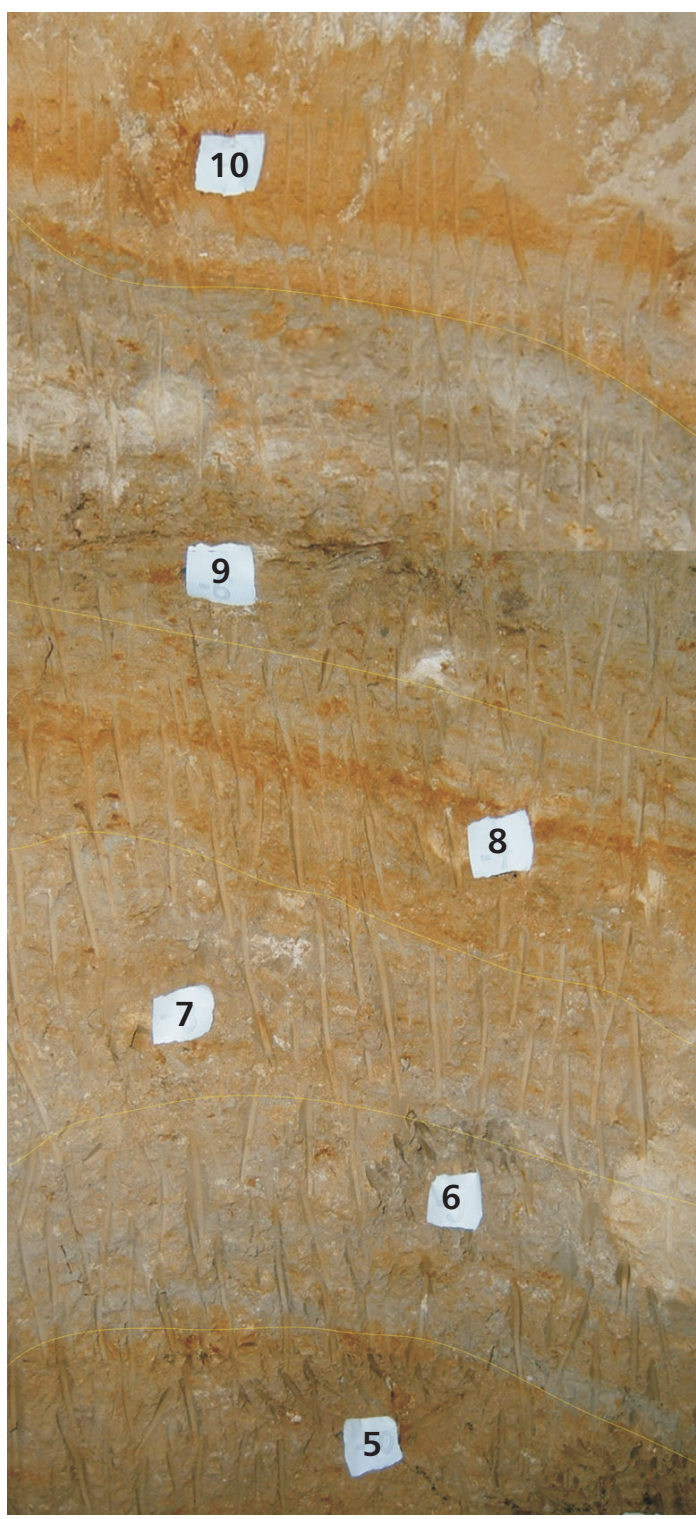

Figure 3. Part of the profile, with indication of collected samples and facies types.

KRAS-9-10). Similarly, Staňková (1977) described volcanic quartzes, volcanic glasses and biotites from the Neogene deposits in the surroundings of Kralice.

The chemistry of detrital garnet is useful and widely used for the determination of provenance (Morton 1991). Results are presented in Fig. 4A, B. A strong dominance of almandine is evident. Only few garnets reveal dominance of grossular, spessartine and pyrope. The data reveal a dominant garnet provenance from metapelites (gneisses and metaschists) and partly also from granulites. Local provenance of material is thus further confirmed.

Rutile represents one of the most stable heavy minerals. It appears primarily in high-grade metamorphic rocks and clastic sediments. Rutile from high-grade metamorphic 
A

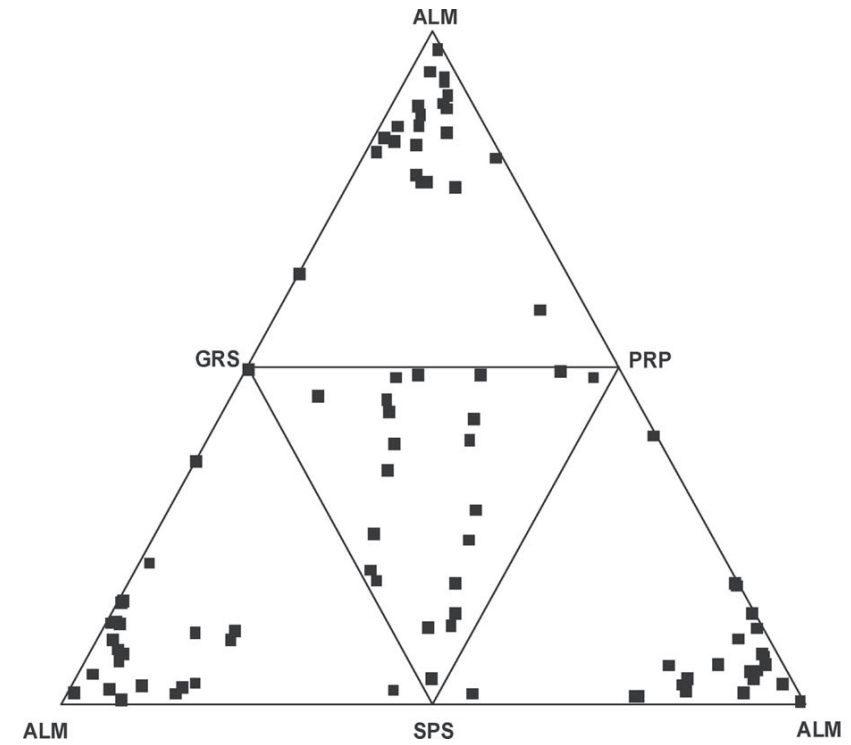

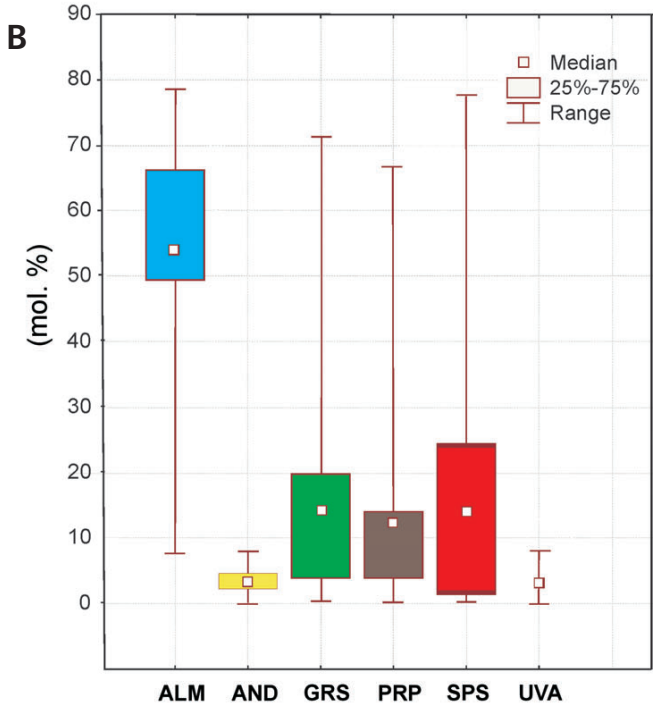

Figure 4. Composition of garnet in ternary diagrams (a) and comparison of garnet composition (b) in section Kralice III. Abbreviations: ALM - almandine, AND - andradite, GRS - grossular, PRP - pyrope, SPS - spessartine, UVA - uvarovite).

rocks is always newly formed and does not contain information from previous metamorphic cycles. This makes rutile attractive for provenance analyses (Force 1980, Zack et al. 2004a, Triebold et al. 2005). Nb, Cr and Zr concentrations in rutile can be used for provenance studies (Zack et al. 2004a, Triebold et al. 2005). Concentration of $\mathrm{Nb}$ in the studied rutiles varies between 330-365 ppm, Cr between 170-180 ppm and Zr between 423-451 ppm. The relatively low content of both $\mathrm{Nb}$ and $\mathrm{Cr}$ can be interpreted as evidence of provenance from metamorphic rocks and the metamorphic temperature (Zack et al. 2004b) can be estimated to have been between 763 and $771{ }^{\circ} \mathrm{C}$ (amphibolite/granulite facies?).

\section{Characteristics of fossil assemblages}

Bryozoa. - Bryozoan remains were found in all studied samples except sample KRAS-6. However (as shown in Appendix B), the number of species is very limited in samples KRAS-1 and KRAS-3 to 5. The association is, compared with other assemblages from the Carpathian Foredeep, relatively diversified, and consists of 42 species.

According to the composition, two associations may be distinguished. The assemblage of the sample KRAS-2 may be correlated with that reported by Zágoršek et al. (2007a) from section Kralice II. Both are characterized by the abundance of Tervia and Reteporella and the occurrence of Reteporella kralicensis. The samples KRAS-7 to 12 are more similar to other sections studied in the Carpathian Foredeep (e.g., Židlochovice, Podbřežice or Holubice) with an abundance of Smittina, Schizoporella geminipora and celleporids (Zágoršek et al. 2004, Zágoršek \& Vávra
2007). However, the abundance of fragments of Vibracella trapezoidea is unusual as it is very rare in other sections in the Moravian part of the Carpathian Foredeep.

Foraminifera. - Generally, all samples were rich in foraminifera. The whole section is characterized by low relative abundance of high nutrient markers and very low abundances of euryhaline species. Three types of benthic foraminiferal assemblages can be distinguished:

Asterigerinata-Lobatula assemblage (Fig. 5B, F, G, H, J, $\mathrm{N}, \mathrm{O}, \mathrm{Q}, \mathrm{T}$ and $\mathrm{X}$ ) were recorded in samples KRAS-1 to 3 . Foraminiferal number markedly increased in this interval, the P/B-ratio is constant and reaches values of about $50 \%$. Globorotalia bykovae and Globigerina praebulloides dominate in planktonic foraminiferal assemblages (Fig. 6D-F, N and Q). The number of benthic, as well as planktonic species, is high (30-33 benthic, 9-11 planktonic). The ratio of herbivore, detrivore and suspension feeders is constant: the relative abundances of herbivore foraminifers and suspension feeders are similar and oscillate around $40 \%$, detrivore foraminifera do not exceed $20 \%$. The BFOI reaches mean values of $65-75 \%$. Based on the composition of the assemblage, a palaeodepth of $100 \mathrm{~m}$ can be interpreted, although the calculated palaeodepth is higher (Fig. 7).

Nonion-Hanzawaia-Bulimina assemblage (Fig. 5S, L, $\mathrm{M}, \mathrm{P}, \mathrm{S}, \mathrm{V}, \mathrm{W}$ and $\mathrm{Y}$ ) occur in samples KRAS-4 to 6 . Foraminiferal number culminates in the sample KRAS-5 and than starts to decrease. The P/B-ratio remains at high values and composition of planktonic foraminiferal assemblages do not change from that in the previous interval. Numbers of benthic species remain at a high level (31-32). In this interval, detrivore foraminifers and passive suspension feeders dominate, herbivore foraminifera are less 


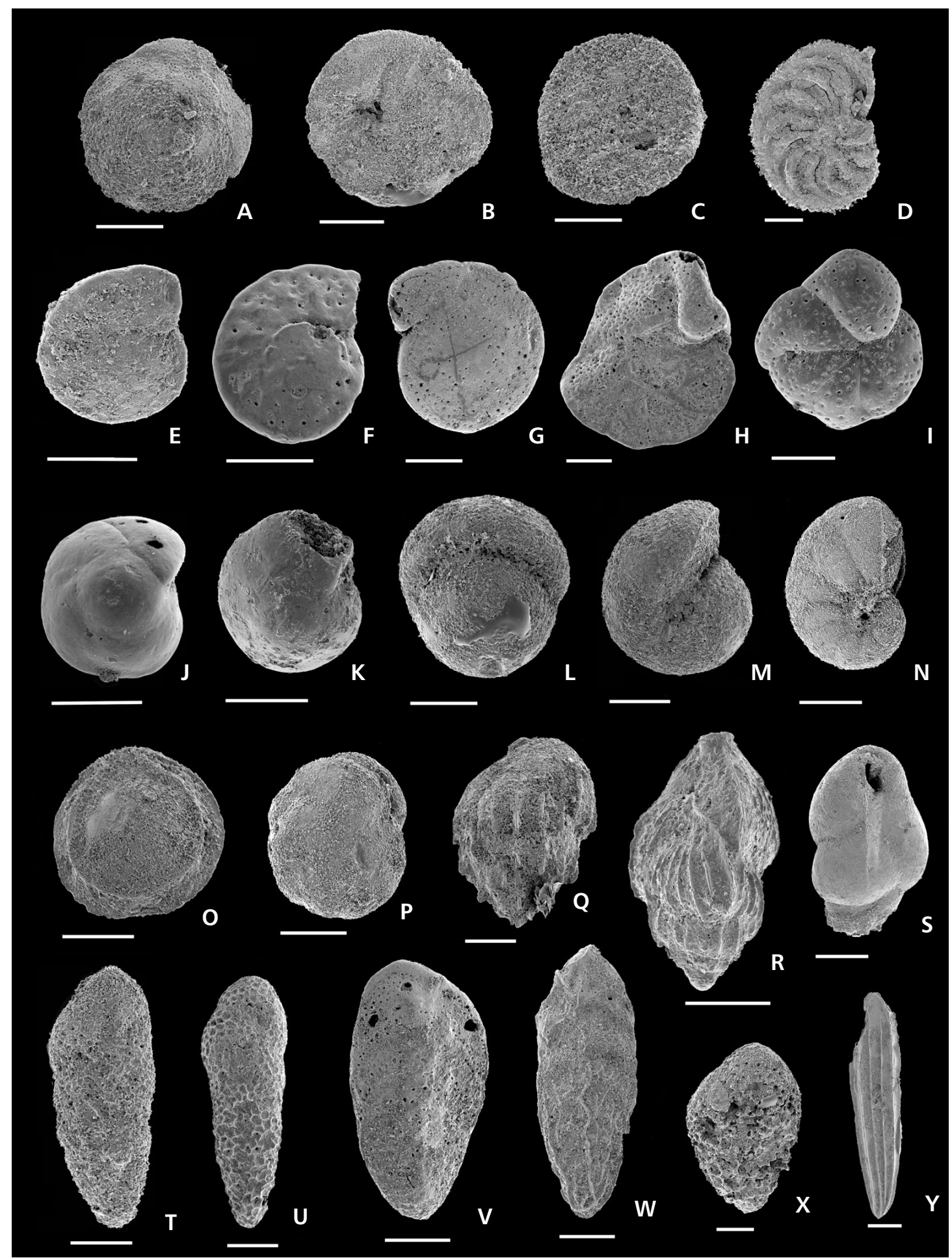

Figure 5. Benthic foraminifera. $\bullet A-$ Asterigerinata planorbis (d'Orbigny), spiral view. $\bullet$ B - Asterigerinata planorbis (d'Orbigny), umbilical view. $\cdot \mathrm{C}-$ Asterigerinata planorbis (d'Orbigny), umbilical view. $\bullet \mathrm{D}-$ Elphidium fichtelianum (d'Orbigny). $\bullet \mathrm{E}-$ Cibicidoides sp. (small-sized), spiral view. $\bullet \mathrm{F}-$ Cibicidoides sp. (small-sized), spiral view. $\bullet \mathrm{G}-$ Heterolepa dutemplei (d'Orbigny). $\bullet \mathrm{H}-$ Lobatula lobatula (Walker \& Jacob). $\bullet \mathrm{I}-$ Lobatula lobatula (Walker \& Jacob). $\bullet \mathrm{J}-$ Alabamina $\mathrm{sp} . \bullet \mathrm{K}-$ Alabamina $\mathrm{sp} \cdot \bullet \mathrm{L}-$ Pullenia bulloides (d'Orbigny), lateral view. $\bullet \mathrm{M}-$ Pullenia bulloides (d'Orbigny), spiral view. $・ \mathrm{~N}-$ Nonion commune (d'Orbigny). $\bullet \mathrm{O}-$ Porosolenia sp. $\bullet \mathrm{P}-$ Cassidulina laevigata d'Orbigny. $\bullet \mathrm{Q}-$ Uvigerina cf. macrocarinata Papp \& Turnovsky. $\bullet \mathrm{R}-$ Angulogerina angulosa (Williamson). $\bullet \mathrm{S}-$ Bulimina subulata Cushman \& Parker. $\bullet \mathrm{T}-$ Bolivina plicatella Cushman. • U - Lapugyina schmidi Popescu. $\bullet \mathrm{V}-$ Bolivina dilatata Reuss. $\bullet \mathrm{W}-$ Bolivina viennensis Marks. $\bullet \mathrm{X}-$ Bolivina hebes Macfadyen. - Y - Plectofrondicularia digitalis (Neugeboren). KRAS-1: H, J, N, Q; KRAS-2: B; KRAS-3: F, G, O, T, X; KRAS-4: P, U; KRAS-5: J, L, R, S, V, W, Y; KRAS-8: C; KRAS-9: E; KRAS-10: K; KRAS-11: A, I; KRAS-12: D. Length of scale bar $100 \mu \mathrm{m}$. 
common. This interval is characterized by the highest relative abundances of infaunal species, corresponding to low values of BFOI (45-60\%). The calculated palaeodepth reaches values between $270-340 \mathrm{~m}$. The palaeogeographic situation as well as sedimentology showed that these palaeodepth ranges were not possible for the Kralice area. A palaeodepth of above $100 \mathrm{~m}$, interpreted from the specific composition of the assemblage, is more probable.

Cibicidoides assemblage (Fig. 5A, E and I) appeared in the sample KRAS-7 and markedly differ from the underlying assemblages. The assemblage is characterized by low foraminiferal numbers and a low P/B-ratio. In sample KRAS-10 planktonic foraminifera are very rare. Diversity of both the benthic and planktonic foraminifera decreases in this interval. Passive suspension feeders dominate in the assemblage. Very low relative abundances of the infauna correspond to high values of BFOI (85-100\%). Bed-load transport of foraminiferal tests has been interpreted from the abraded and corroded tests in samples KRAS-10, 11. Calculated palaeodepth estimates reached values of 35-100 m which corresponds with the estimation of palaeodepth based on the specific composition of the assemblage.

Calcareous nannoplankton. - Calcareous assemblages are common to rare and their diversity is low (4-7 autochtonous species). Two assemblages can be distinguished: 1) Reticulofenestra minuta-Coccolithus pelagicus assemblages were recorded in samples KRAS-1 to 6. Abundances of calcareous nannoplankton assemblages are high and peak in the sample KRAS-4. The number of species as well as the relative abundance of $C$. pelagicus slightly decreases upwards. At the top of this interval (sample KRAS-6), taxa reworked from the Oligocene (Reticulofenestra abisecta, R. bisecta, R. umbilica and Helicosphaera euphratis) start to appear. 2) Reticulofenestra minuta-Thoracosphaera assemblage occur in the upper part of the section (samples KRAS-7 to 12). Calcareous nannoplankton are rare and with low diversity. Practically only $R$. minuta, Coccolithus pelagicus and Thoracosphaera spp. occur in the assemblage.

Molluscs. - Molluscs were most common in sample KRAS-9, and were lacking only in sample KRAS-8. From sample KRAS-5 upwards, mollusc abundance increases, similar to other groups (echinoderms, bryozoans). The mollusc fauna consists predominantly of bivalves. Fragments of pectinids dominate. Chiton fragments are rare and gastropods are completely absent (Hamršmíd 1984). The fauna documented here is similar to results published previously (Procházka 1893, Toula 1893, Janoschek 1937, Hamršmíd 1984), but less diverse, owing to the fact that only bulk samples were studied. The systematics and palaeoecological evaluation is based on work by Bagdasaryan et al. (1966), Steininger et al. (1978), Studencka
(1986), Studencka et al. (1998), Schultz (2001), Mandic \& Harzhauser (2003) and Mandic (2004).

Echinoderms. - In total more than 2200 echinoderm ossicles were recovered from the bulk samples take at the Kralice section. The lower part of the section (KRAS-1 to 8) is relatively poor in echinoderm remains, both in terms of diversity (7 taxa), as well as in abundance, accounting for only about one quarter of the echinoderm remains collected. In three levels (KRAS-1, 4, 8) echinoderms are particularly rare. In the upper part of the section (KRAS-9 to 12 ), in contrast, echinoderms are very abundant and diversity doubles (15 taxa). Samples KRAS-9, 10, are particularly rich, together accounting for more than $50 \%$ of the material. Upsection both diversity and abundance decline again, but stay significantly higher than in the lower part.

Asteroid percentage varies considerably throughout the section, peaking in samples KRAS-4 to 6, corresponding to nearly $40 \%$ of the echinoderm material from these samples. A second, less pronounced asteroid peak occurs in samples KRAS-10 to 12 . Spatangoid abundance is high throughout the profile, declining only slightly in those samples where asteroids peak (KRAS-4 to 6).

The fact that apart from the more massive cidaroid spines, no echinoid spines have been recovered from the bulk samples is an effect of the sieve size employed (echinoderms were studied only from fractions larger than $2 \mathrm{~mm}$ ). The same reason may account for our inability to recover any ophiuroid or holothurioid ossicles which were recorded from this section by Hamršmíd (1981, 1984).

\section{Interpretation}

\section{Biostratigraphy}

Section Kralice III can be well correlated with the planktonic foraminiferal standard (Berggren et al. 1995), as well as Paratethyan zonations (Rögl 1986, Cicha et al. 1998, Harzhauser \& Piller 2007). Correlation (Fig. 8) was based on the co-occurrence of planktonic foraminiferal species $O r$ bulina suturalis and Globigerinoides bisphericus (Fig. 6D-F, N and Q) and thus this section can be correlated with the lower part of the Upper Lagenid Zone (Grill 1941, Papp \& Turnovsky 1953, Hohenneger et al. 2007). This age corresponds with the base of the Bryozoan events (Zágoršek et al. 2007b, Holcová \& Zágoršek 2008) of the Middle Miocene of the Alpine-Carpathian region. Planktonic foraminifers are rare in the upper part of the section (KRAS-10 to 12) and therefore the last occurence of G. bisphericus in sample KRAS-9 is not considered significant and thus not used for biostratigraphical correlation.

Calcareous nannoplankton assemblages do not contain Helicosphaera ampliaperta which may indicate correla- 


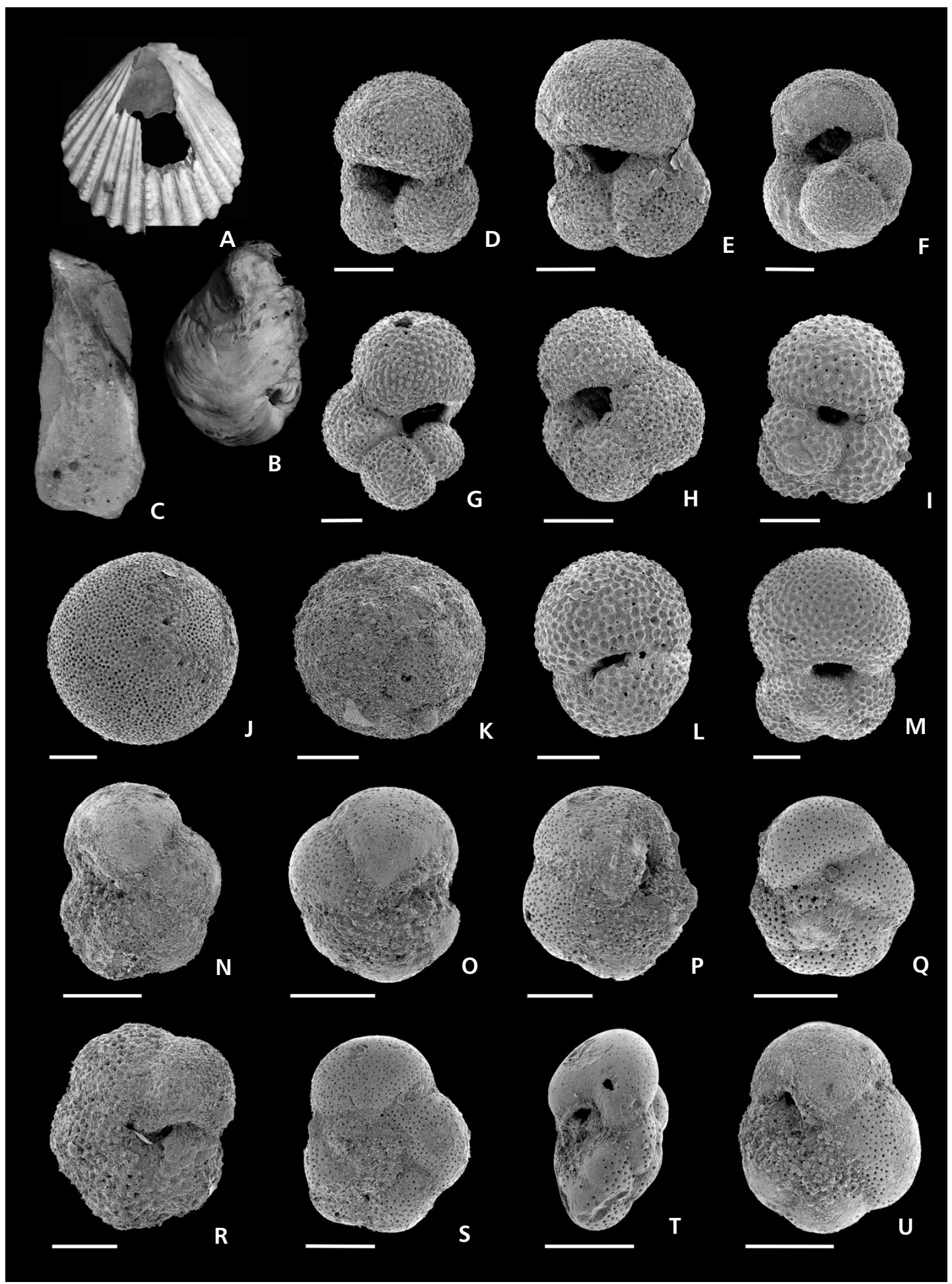

Figure 6. Mollusca. • A - Aequipecten macrotis (Sowerby in Smith), juvenile specimen, shell length $8 \mathrm{~mm} \cdot \bullet \mathrm{B}-$ Neopycnodonte cf. navicularis (Brocchi), juvenile specimen, shell length $8 \mathrm{~mm}$. $\mathrm{C}$ - Costellamussiopecten cristatus badense (Fontannes), fragment, shell length $10 \mathrm{~mm}$. Planktonic foraminifera. $\bullet \mathrm{D}-$ Globigerina praebulloides Blow. $\bullet \mathrm{E}-$ Globigerina praebulloides Blow. $\bullet \mathrm{F}-$ Globigerina praebulloides $\mathrm{Blow} \cdot \bullet \mathrm{G}-$ Globigerinella regularis (d'Orbigny). $\bullet \mathrm{H}-$ Globigerina lentiana Roegl. $-\mathrm{I}$ - Globigerinoides quadrilobatus (d'Orbigny). $・ \mathrm{~J}$ - Orbulina suturalis Bronnimann. $\cdot \mathrm{K}$ - Orbulina suturalis Bronnimann. $\bullet \mathrm{L}$ - Globigerinoides bisphericus Todd. $\bullet \mathrm{M}-$ Globigerinoides trilobus (Reuss). $\bullet \mathrm{N}-$ Globorotalia bykovae (Aisenstat). $\bullet \mathrm{O}-$ Globorotalia bykovae (Aisenstat). $\bullet \mathrm{P}-$ Globorotalia bykovae (Aisenstat). $\bullet \mathrm{Q}-$ Globorotalia bykovae (Aisenstat). $\bullet \mathrm{R}-$ Paragloborotalia mayeri (Cushman \& Ellisor). $\bullet \mathrm{S}-$ Globorotalia bykovae (Aisenstat). $\bullet \mathrm{T}-$ Globorotalia bykovae (Aisenstat). $\bullet \mathrm{U}-$ Globorotalia bykovae (Aisenstat). Length of scale bar $100 \mu \mathrm{m}$. KRAS-1: D, H, I, M, N, Q, R; KRAS 3: E, F; KRAS 4: L; KRAS 5: C, G, H; KRAS 6: O, P, S; KRAS 8: T; KRAS 11: A, K; KRAS 12: B. 
tion with NN5 Zone although positive evidence is lacking as $S$. heteromorphus was not recorded.

For stratigraphical correlations of sediments from section Kralice III, pectinid bivalves are the most characteristic elements of the mollusc fauna. Albeit most species exhibit wide stratigraphic ranges, a few are useful for correlation. Oopecten solarium does not occur before the Badenian in the Central Paratethys (possible occurrences in the Karpatian are doubtful; see Mandic 2004). Another characteristic Badenian taxon is Costellamussiopecten spinulosus. Even the species Aequipecten malvinae and "Ch." trilirata are stratigraphically important, as their FOD lie above the base of the Middle Miocene in Paratethys, with Aequipecten malvinae occurring continuously during the Badenian, "Chlamys" trilirata only in the Lower and ?Middle Badenian. Thus, the presence of these species excludes both Early Miocene and Late Badenian ages for the sediments at Kralice. Based on mollusc fauna, the age of sediments at Kralice can thus be interpreted as Badenian, most probably Early Badenian (based on the occurrence of "Ch." cf. trilirata).

The comparison of pectinid bivalves from Kralice with pectinid bivalves from the Grund Formation in the Alpine-Carpathian Foredeep in Lower Austria (Mandic 2004) shows that the majority of species occur in both areas. At Kralice, however, the species $C$. cf. spinulosus is present, which is entirely absent in the Grund Formation Lower Lagenidae Zone; Mandic 2004). This species is typical only for upper parts of the Lower Badenian (Upper Lagenidae Zone; Mandic 2004) and its occurrence at Kralice indicates the sediments at this locality (at least from the sample KRAS-5) are slightly younger than the sediments of the Grund Formation.

The data from various biostratigraphically significant fossils is thus in strong agreement and indicates an Early Badenian age for the studied section. The echinoderm and bryozoan faunas of Kralice contained few age-indicative forms, but generally support the Early Badenian ages.

\section{Depositional environment}

Subhorizontal bedding and low thickness of individual beds can be connected with a pulsed nature of sedimentation. The absence or rarity of primary sedimentary structures is connected with strong bioturbation.

Facies F4 and F1 may originate from marine environments below the fair-weather wave base. Deposition from suspension strongly predominates. Deposition of marine mudstone or muddy limestone is usually explained by a pelagic environment, deeper depositional settings, steadystate style of deposition and the important role of suspension fallout. Presence of coarser sandy material, scattered pebbles and shell detritus within these facies is usually explained by the role of storms or density flows/gravity cur- rents, Scott et al. 2004, Ilgar \& Nemec 2005). The amount of re-deposition of fossils debris from a shallow marine environment also varies.

Facies F2 can be interpreted as a product of deposition in marine/offshore settings with an episodic input of coarser material. Absence of sedimentary structures induced by waves or tidal activity reveals deposition in offshore conditions. Erosion and re-deposition of shells in a coastal environment, their transport offshore by gravity currents or storm induced flows (tempestites) and their rapid deposition is presumed. Horizontal lamination connected with mudstone laminas point to a pulsed nature of sedimentation. Deposition from sediment gravity currents typically occurs in an episodic fashion against background deposition.

Facies F3 reveals a typical textural inversion, which can be explained by highly different conditions of deposition/transport of individual sediment particles. A depositional environment and conditions identical with the ones of facies F2 can be in general supposed. Transport of isolated, outsized, angular pebbles can be explained by rock falls (Nemec 1990). Relative dramatic relief of the basin bottom and re-deposition of the large pebbles into the offshore conditions by density currents may be expected. A coastline with gravel beaches is not expected due to the angularity and local provenance of pebbles. Nehyba (2003) documented the originally broad extent of the Lower Badenian Neogene deposits in the surroundings of Kralice, their post-depositional erosion and re-deposition into younger sediments.

\section{Palaeoecological interpretation based on studied groups of fossils}

Foraminifera and calcareous nannoplankton. - From the low relative abundances of euryhaline species, normal salinity can be interpreted for the whole section. Oscillation of BFOI index indicates oscillation of oxygen content in the sediment: the lowest values of oxygen in sediment are expected in the interval KRAS-4 to 6 where relative abundances of detrivore infauna markedly increase. Very high values of oxygen content in both sediment and water column are interpreted for the interval KRAS-7 to 12. In the upper part of this interval, a dynamic environment with bedload transport of foraminiferal tests is recorded. Based on the occurrence of epifaunal foraminifera in the whole interval, the presence of sea-grass meadows can be expected, with the exception of samples KRAS-4 to 6 (Fig. 9).

Palaeodepth estimation shows deepening of the environment towards the samples KRAS-4 to 6 (above $100 \mathrm{~m}$ ) and a shallowing trend above. The shallowing can be correlated with decreasing of P/B-ratio and appearance of the stress marker Thoracosphera in the calcareous nanno- 


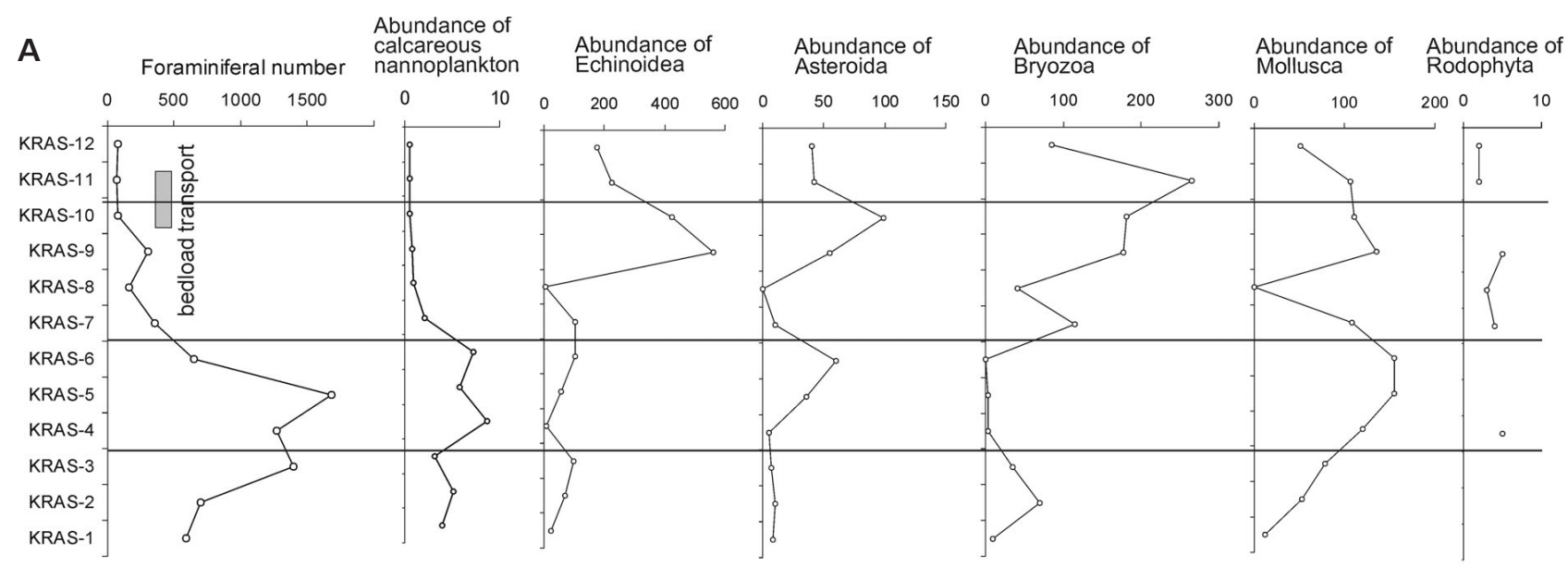

B
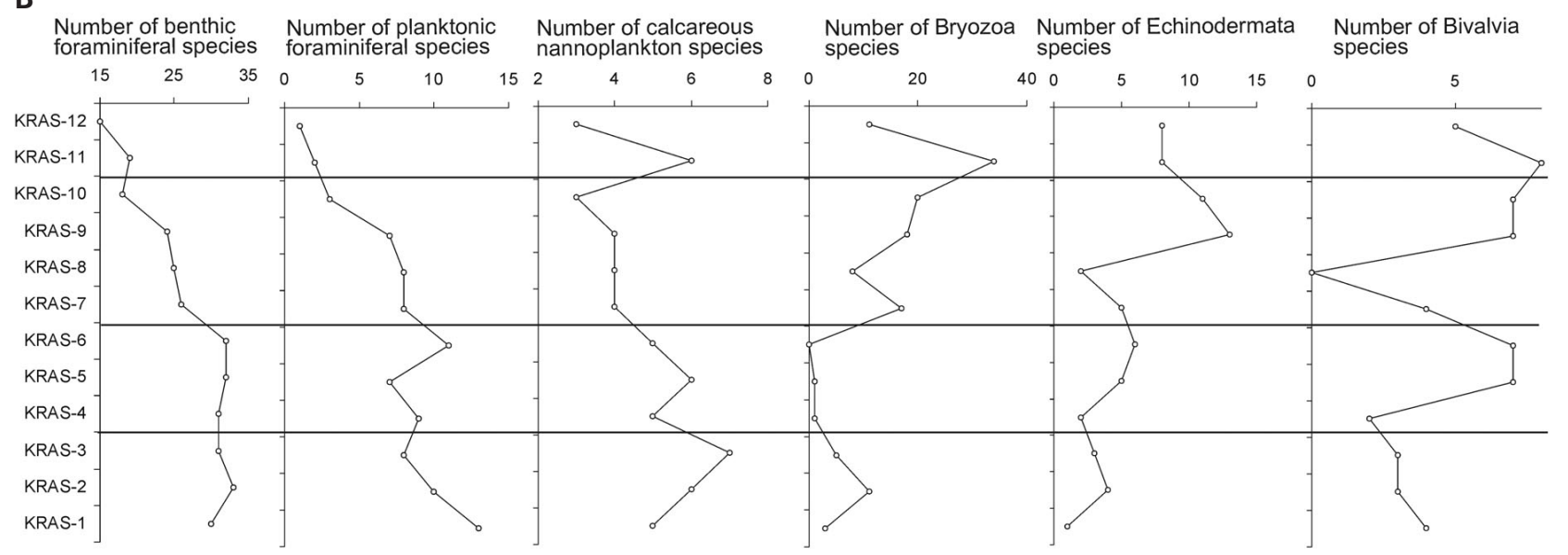

Figure 7. Changes in abundances (part A) and diversities (part B) of the studied fossil groups. Diversities are represented by number of species in assemblages, detailed explanation of abundance indexes in text (Methods chapter).

plankton assemblages and gradual decrease of diversity of benthic foraminifera. A marked decrease in abundance of calcareous nannoplankton and foraminifera between samples KRAS-7, 6 could be caused by a decrease in their primary productivity or increase in input of terrigenous material. Dominance of suspension feeders among benthic foraminifers indicates sufficient nutrition levels, despite the decrease of calcareous nannoplankton. A high negative correlation between foraminiferal abundance and number of Bryozoan species $(r=-67)$ has been pronounced throughout the profile (Fig. 9).

Mollusca. - The mollusc fauna represents a mixture of different environments, as indicated by the faunal composition and shell preservation. Costellamussiopecten which occurs continuously in the whole profile, prefers deeper quiet waters without strong currents and rather soft clay substrate, being like many other pectinid species, an efficient active swimmer (Bagdasaryan et al. 1966).

The pectinids ("Chlamys" trilirata and Aequipecten macrotis) possessing thin shells belong to epibionts usually exhibiting byssal attachment to the substrate. For the shell attachment they needed primary and secondary hard substrates. They are predominantly recorded from rocky sublittoral environments (Mandic \& Harzhauser 2003), namely in a less exposed, somewhat deeper infralittoral (shallow subtidal) zone (Fig. 6A).

The oyster Ostrea digitalina is typical for a rocky coastline environment with dominant wave action, e.g., for the highly exposed rocky medio/sublittoral (intertidal to shallow subtidal) to depths of $10 \mathrm{~m}$ (Mandic \& Harzhauser 2003). On the contrary, Neopycnodonte navicularis (Fig. 6C) prefers greater depths (below $40 \mathrm{~m}$; Bagdasaryan et al. 1966). In the studied material from Kralice, the oysters occurred only sporadically. The lack of right valves indicates transport and/or sorting. In all cases juvenile shells were found, probably more predisposed than adult specimens to mechanical tearing off of the hard substrate.

Most molluscs reported from Kralice-III are thus elements of deeper infralittoral (samples KRAS-3 and 4), enriched to various degrees with the admixture of species 


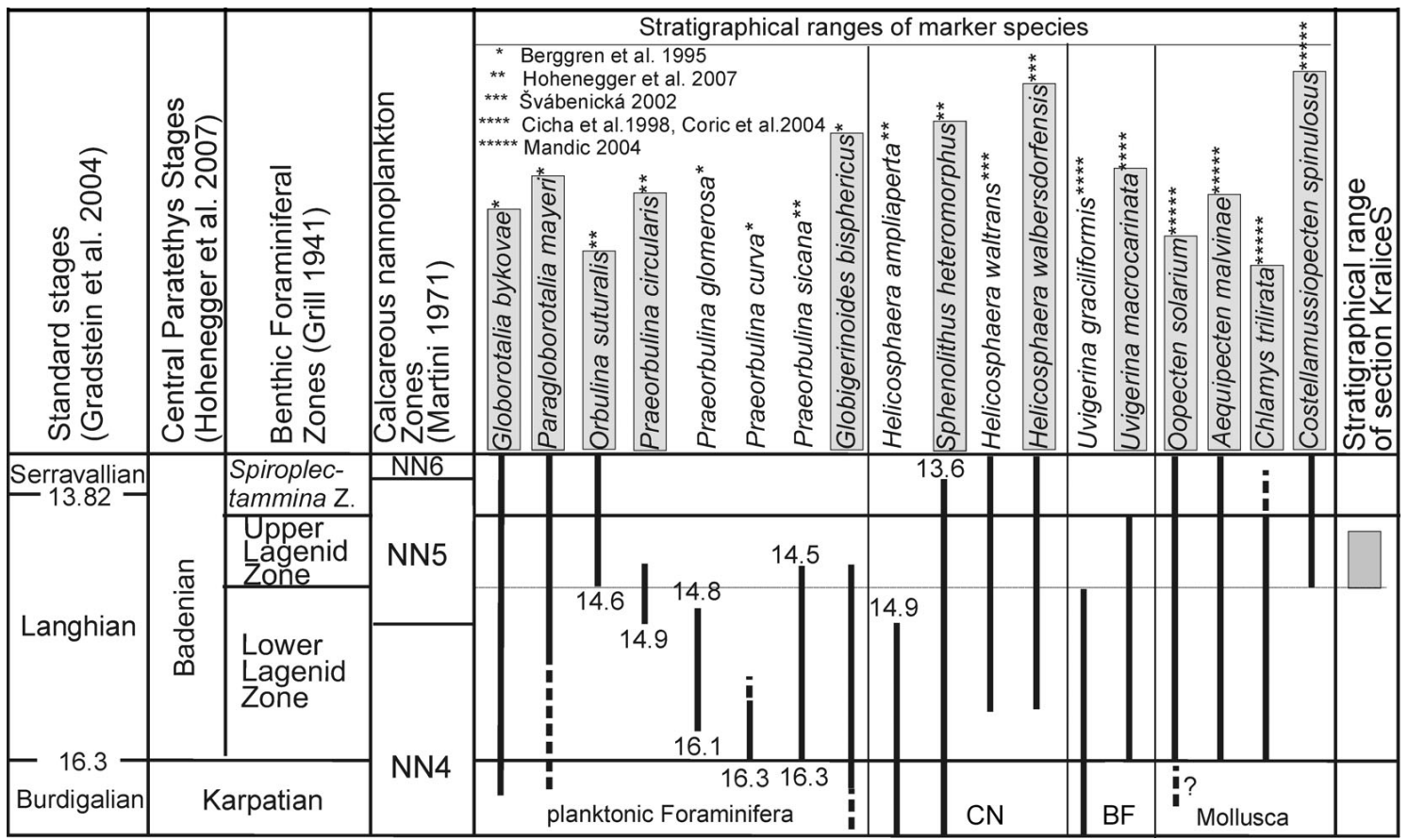

Figure 8. Biostratigraphical correlation of Kralice III. Biostratigraphy is based on calcareous nannoplankton, planktonic and benthic Foraminifera and Mollusca. Species in gray rectangles occur in the section Kralice III. CN - calcareous nannoplankton, BF - benthic Foraminifera.

re-deposited from shallower sublittoral settings (samples KRAS-1, 2, ?5, 7, 11, and 12), even rarely from a highly exposed rocky coastline (samples KRAS-6, 9, and 10). The predominance of thin-shelled undeterminable bivalve fragments in most samples indicates a quieter sedimentary environment. The mixing of elements from different habitats indicates higher water dynamics.

The presence of stenohaline bivalves, namely from the family Pectinidae, together with the almost total absence of brackish and estuary elements, as well as occasional brachiopod shells, confirm a fully marine $(\sim 35 \%$ o $)$ sedimentary environment.

Among the bivalves recorded, suspension feeders are unequivocally dominating, confirming the marine environment to be rich in organic detritus and planktonic micro-organisms. Representatives of bryozoans and brachiopods are also suspension feeders. The abundant remains of echinoderms, especially asteroids and echinoids, represent another trophical level - carnivores/predators (asteroids), and scavengers (asteroids, cidaroids) whose main food source may have been represented by the molluscs.

Echinodermata. - The Kralice echinoderm assemblage is dominated by burrowing spatangoids (detrivores), followed by burrowing and epibenthic asteroids (predators and scavengers). The faunal composition is characteristic of Badenian near-shore echinoderm assemblages. Water depth for the lower part of the section can be estimated in the order of $c a 15$ to several tens of meters. The increased diversity and abundance in the upper part, with the appearance of shallow-water forms (e.g., Schizechinus, Echinolampas) could be seen as an indication of a shallowing upwards trend. The skeletal material of the shallow-water forms, however, shows a large degree of abrasion, disarticulation and fragmentation. Most of the cidaroid and spatangoid ossicles are remarkably well preserved in comparison. This, together with the taxonomic composition suggests mixing of material from different habitats and down-slope transport of the shallow-water sediment. The latter interpretation is also in strong agreement with the data obtained from the foraminiferal and molluscan fauna (see above) and sedimentology. A similar situation was observed in the Early Badenian of Niederleis, Austria (Mandic et al. 2002, Kroh 2003) where shallow water material was also transported into deeper water settings.

The abundance peak of asteroids in samples KRAS-4 to 6 coincides with indicators for deepening in other organism groups. The increased proportion of asteroid remains may be explained by the loss of herbivorous taxa, due to a sea level rise, which were dependant on marine plants. Unlike many echinoid groups the asteroids recorded here were not affected by this environmental change due to their predatory/scavenger type of feeding.

Bryozoa. - Rich occurrence of Schizoporella geminipora in the samples KRAS-9 to 11 indicate algal (Posidonialike) meadows on the bottom of the sea, closed to the 


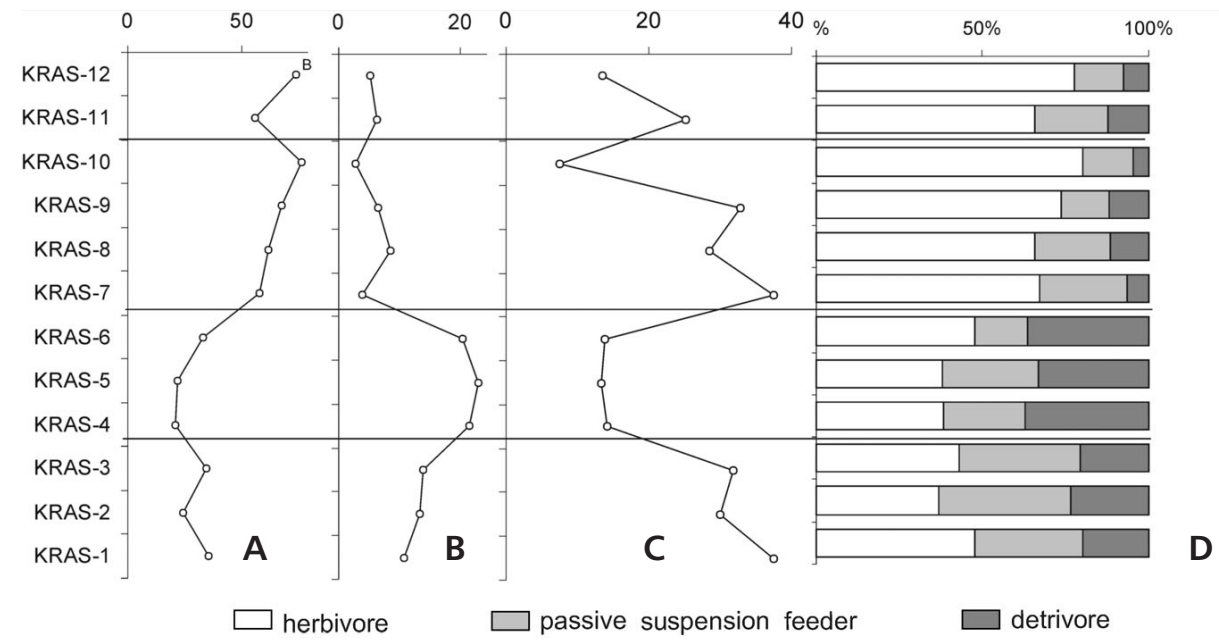

Figure 9. Foraminiferal indexes used for interpretation of paleoenvironment. Relative abundances of A - oxiphylic species, B - infaunal species, C - epiphytic species. - D - BFOI (= benthic foraminiferal oxygen index, Kaiho 1994). $\bullet$ E - estimation of paleodepth according to foraminiferal plankton/benthos ratio (van der Zwaan et al. 1990). • F - relative abundances of benthic foraminifera with different feeding strategy. - $\mathrm{G}$ - foraminiferal plankton/benthos-ratio (P/B-ratio). $\bullet \mathrm{H}-C$. pelagicus/R. minuta-ratio (calcareous nannoplankton). $\bullet$ I - relative abundance of Thoracosphaera (calcareous nannoplankton).

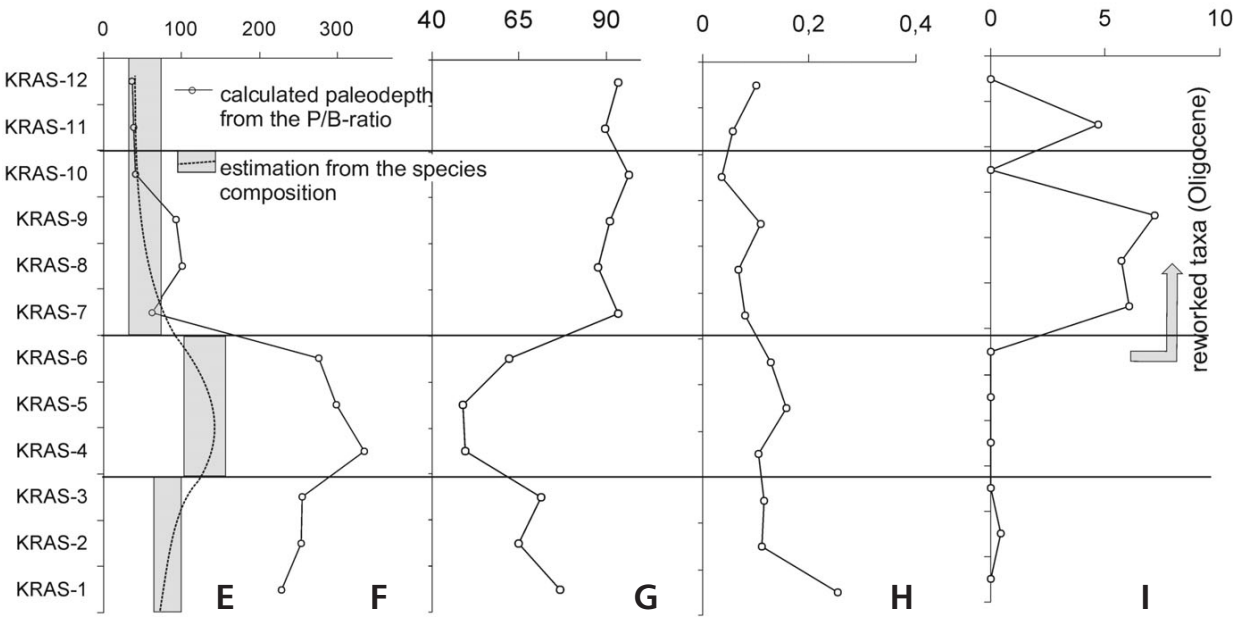

depositional area (Vávra 1984). The presence of Posidonia-like green algae may be supported also by the common occurrence of Reteporids, which recently live attached to algae in the Mediterranean (Zabala \& Malaquer 1988).

Kionidella from the samples KRAS-7 and 9 belong to the genera which developed conical colonies characteristic for rooted species (McKinney \& Jackson 1984). The common occurrence of this genus indicates soft but not clayish substrates. This interpretation can also be supported by the occurrence of Vibracella, which lived lying flat on the seafloor and would have been adversely affected by a high suspension load in the water column.

\section{Succession of assemblages and palaeoenvironmental changes in the Kralice section}

According to the fossil content and sedimentology investigation, four intervals in the Kralice III profile can be distinguished as indicated in Figs 7 and 9.
1) The first interval, represented by samples KRAS-1 to 3 , is characterized by the rare occurrence of Bryozoa and other macrofossils. Asteroids and echinoids manifest low diversity; the diversity of molluscs drops progressively, reaching its lowest local value in sample KRAS-4, in spite of the slightly increased abundance of their fragments. Echinoderms and bryozoans show a small peak of diversity and abundance in sample KRAS-2. Nannoplankton, in contrast, reveal both high diversity and abundance, which may indicate a transgressive setting. Similarly also Asterigerinata - Lobatula assemblage show high diversity.

This interval can be compared with sample KRAT 9 from the section Kralice II (Zágoršek et al. 2007a). All bryozoan species recorded in the section Kralice II also occur in the section Kralice III, with a few additional rare species. The time interval can be clearly correlated (co-occurrence of $G$. bisphericus and Orbulina) and therefore these two occurrences probably represent the same bryozoan event. Lithofacially, these samples (KRAT 9 and KRAS-1 to 3 ) belong to the facies type 1 (F 1 ).

Samples KRAS-1 to 3 were deposited in an infralittoral 
environment with sea-grass meadows and well oxygenated water. On the contrary, a deeper infralittoral environment (more than $100 \mathrm{~m}$ ) with absence of sea grass, corresponding to the virtual absence of epifaunal foraminifers, was suggested for the sample KRAT 9 from section Kralice II (Zágoršek et al. 2007a). Due to the short distance between sections Kralice II and Kralice III, the palaeoecological differences may be explained by displacement episodes. Gravity flows may have transported the shallow water epifaunal foraminifers to the deeper environment, but the absence of postmortal transport indicators (test preservation and size sorting of foraminiferal tests) does not support the suggestion of redeposition.

The coexistence of a deeper infralittoral fauna with sea-grass meadows may be connected with very variable morphology of the sea bottom, creating small-sized, variegated biotopes, which may be mixed in the sedimentary record.

2) Samples KRAS-4 to 6 show the highest abundance of foraminifers and calcareous nannoplankton in the section, and an abundance peak for molluscs and asteroids. Bryozoans and echinoids, in contrast, are very rare, sometimes almost absent. The bryozoan and echinoid diminution is correlated with a decrease of oxygen content inside the bottom sediment as indicated by benthic foraminiferal evidence and/or food availability. Bryozoans probably lost suitable surfaces for inhabitation.

Water without permanent strong currents may be indicated by the highest abundance of thin-shells Costellamussiopecten. Samples KRAS-5, 6 show high fragmentation of the mollusc shells and an admixture of elements from the shallow subtidal and highly exposed rocky coastline. These may indicate an episodic increase in dynamics of the environment and re-deposition of the material from shallow water.

Molluscs, foraminifers and abundant Rhodophyta indicate a deeper infralittoral in this interval, with maximum palaeodepth perhaps more than $100 \mathrm{~m}$. Increased depth probably induced a decrease of oxygen inside the sediment due to the higher flow of organic detritus inside the basin. A more proximal position, indicated by the lithofacial analysis (F 2) and mollusc fragments may be explained by an episodic increase in input of clastic material into the basin, and re-deposition of the material from shallow water and therefore is not in contrary with interpretation made from biological markers.

3) Samples KRAS-7 to 10 represent an interval of changes with a general shallowing upwards trend. Storms or density flows/gravity currents and down-slope transport of the shallow-water sediment is documented by material mixing from different habitats.

In sample KRAS-7 a change in terrigenous input begins, which may indicate changes in basin geometry and sediment source area. This change is pronounced by the composition of the heavy mineral association and by presence of reworked Oligocene calcareous nannoplankton.

The change in environmental conditions is also recorded by the re-appearance of Bryozoa, the common occurrence of Rhodophyta and marked decrease in abundance of infaunal foraminifera and calcareous nannoplankton. These biotic changes may indicate an increase in food supply for suspension feeders as concurrent suspension feeders among molluscs, foraminifers and bryozoans could coexists. Among molluscs, an admixture of elements from the shallow subtidal and rocky sublittoral occurs. In comparison with sample KRAS-6, slight calming can be supposed, nevertheless the water dynamics remained constantly high.

Sample KRAS-8 is characterised by lithofacies 4, almost total absence of Echinoidea, Asteroidea, Mollusca, and also by the low abundance of foraminifers and bryozoans. The environment has probably been only slightly influenced by episodic sedimentation (storms or density flows/gravity currents).

KRAS-9 is the only example of facies 3 which indicates shallow marine conditions. This sample is also characterised by an abundant and diverse mollusc content (admixture of elements from highly exposed rocky coastline), and a diversity peak in echinoids, low peak in foraminifera and increase in abundance of asteroids and bryozoans. The increased diversity in echinoids can be related to favourable shallow water conditions with diversified micro-habitats. Alternatively, part of the echinoderm material could be allochthonous as indicated by the high degree of fragmentation and corrosion.

KRAS-10 is similar to KRAS-8 in lithology, but with an abundant and well developed benthos (Asteroidea). On the contrary, Rhodophyta and epifaunal species show a decrease in abundance. Molluscs again indicate admixture of elements from an exposed rocky coastline. First occurrence of bed load transported foraminifers may indicate a shallow, dynamic environment with rocky margins. Episodic storms or density flows/gravity currents might have eroded this surface and transported the benthos from rocky margins to muddy bottom sediments. In general, according to the presence of facial type F4, sedimentation was quieter and shallower than in the lower part of the succession.

4) The samples KRAS-11, 12 are characterised by diversity peaks in bryozoans and bivalves. These samples probably represent stable, very shallow marine conditions, with continuing deposition from rocky coastline, no storms or density flows may be expected. These conditions may be well correlated with other Carpathian Foredeep sections such as Holubice or Přemyslovice (Zágoršek \& Holcová 2005, Holcová et al. 2007) or in the Vienna basin e.g., Hlohovec (Zágoršek \& Vávra 2007, Zágoršek et al. 2004). 


\section{Systematic section}

Phylum Bryozoa Ehrenberg, 1831

Order Cheilostomata Busk, 1852

Suborder Neocheilostomina d'Hondt, 1985

Family Calloporidae Norman, 1903

\section{Genus Pyriporella Canu, 1911}

Pyriporella loxopora (Reuss, 1848)

Figure 10A-C

1848 Cellepora loxopora m. Reuss, p. 97, pl. 11, fig. 24.

1974 Hincksina loxopora (Reuss). - David \& Pouyet, p. 102, pl. 3, fig. 1 .

1977 Hincksina loxopora (Reuss). - Vávra, p. 79.

Material. - 10 specimens (NM PM2-P 1327-PM2-P 1336).

Remarks. - Hincksina Norman, 1903 has spines encircling the opesia (Hayward \& Ryland 1998), which are missing in this species (David \& Pouyet 1974).

Pyriporella, as revised by Taylor \& McKinney (2006), budding numerous small adventitious avicularia which later develop to overgrow autozooecial gymnocyst. This feature is clearly illustrated on studied specimens (Fig. 10B). Pyriporella loxopora is characterised by the chaotic arrangement of the autozooecia and development of many small avicularia.

Family Lunulitidae Gregory, 1893

\section{Genus Vibracella Waters, 1891}

Vibracella trapezoidea (Reuss, 1848)

Figure 10D, E

v. *1848 Cellepora trapezoidea m. Reuss, p. 96, pl. 11, fig. 21.

v. 2003 Vibracella trapezoidea (Reuss). - Zágoršek, p. 138, pl. 14 , fig. 3 .

Material. - 7 specimens NM PM2-P 1337-PM2-P 1343).

Remarks. - The species is mainly known from Late Tertiary sediments (Eocene to Oligocene, Zágoršek 2003), but also rarely occurs in the Vienna basin Miocene (Vávra 1977). The studied specimens are identical with the holotype stored in the Museum of Natural History in Vienna. The presence of adventitious avicularia and endozooecial ovicell are similar to the genus Lunulites and therefore Vibracella is listed in the family Lunulitidae. A different idea, supported mainly by Bock (2008), who according to different development of the avicularia, listed Vibracella among unplaced Anascan Cheilostomata. A detailed revision of the genus is needed for resolve this question.
Family Steginoporellidae Hincks, 1884

Genus Steginoporella Smitt, 1873

Steginoporella cucullata (Reuss, 1848)

Figure $10 \mathrm{H}$

v. *1848 Cellaria cucullata m. - Reuss, p. 60, pl. 7, fig. 31.

v. 2001 Steginoporella cucullata (Reuss). - Zágoršek, p. 40, pl. 9 , fig. 6.

Material. - 6 specimens (NM PM2-P 1344-PM2-P 1349).

Remarks. - Although no vicarious avicularia (B-zooecia) is developed, the other features (short autozooecia, thick marginal walls and small opesiules) clearly identify this species. As noted by David \& Pouyet (1974) the avicularia in this species are extremely rare.

Suborder Ascophorina Levinsen, 1909

Infraorder Umbonulomorpha Gordon, 1989

Family Umbonulidae Canu, 1904

\section{Genus Umbonula Hincks, 1848}

Umbonula macrocheila (Reuss, 1848)

Figure 11C

v. * 1848 Eschara macrocheila; Reuss, p. 65, Pl. 8, fig. 14.

v. 1989 Umbonula macrocheila (Reuss). - Schmid, p. 31, Pl. 8, fig. 1-4.

1997 Umbonula macrocheila (Reuss, 1848). - Pouyet, p. 50, Pl. 4, fig. 10; Pl. 5, fig. 5.

v. 2003 Umbonula macrocheila (Reuss). - Zágoršek, p. 160, pl. 23 , fig. 5 .

2003 Umbonula macrocheila (Reuss, 1848). - Zágoršek, p. 160 , pl. 23, fig. 5 .

Material. - 4 specimens (NM PM2-P 1350-PM2-P 1353).

Description. - Colony encrusting. Autozooecia oval with convex, smooth frontal wall, characteristically with ribs extending from marginal areolar pores through the frontal wall and ending on the top of the umbo. Marginal areolar pores of medium size, approximately $10-15$ pores around each autozooecium. Aperture large, oval with concave proximal margin. Adventitious avicularium, without pivotal bar, is situated on the middle of the frontal wall, proximally from the aperture, on the top of the umbo. It may rarely be developed as a giant avicularium with pivotal bar and oval rostrum. No suboral avicularia. Ovicell partly immersed, globular with "U" shaped arranged pores on frontal wall. 
Remarks. - As shown by Schmid (1989) and Pouyet (1997) Eschara macrocheila and Cellepora endlicheri Reuss, 1848 represent same species. The variability of avicularia and also general habitus have been discussed by Schmid (1989). Characteristic features are large umbo on middle of the frontal wall and large areolar pores. Note, that the rest of the frontal wall surface is smooth and flat.

\section{Umbonula spinosa (Procházka, 1893)}

Figure 11D-G

* 1893 Eschara spinosa n. sp. - Procházka, p. 51, Pl. 12, fig. $5 \mathrm{a}-\mathrm{g}$.

v. 1996 Umbonula spinosa (Procházka).-Sváček, p. 72, fig. 1.

Material. - Neotype erected here NM PM2-P 1354 and 14 specimens (NM PM2-P 1355-NM PM2-P 1368).

Diagnosis. - The colony is erect, massive. The autozooecia are oval and have a convex, frontal wall with small marginal areolar pores (about 10-15 pores around each autozooecium). Umbonuloid frontal wall is well developed and clearly visible from inside the autozooecia (Fig. 11G). The frontal wall developed characteristic small umbos resembling short spines (the name of the species is derived from these short spines). The additional small umbos on the frontal wall do not carry any avicularia. The aperture is large and oval. Primary orifice developed wide lyrula. A small adventitious circular avicularium, without pivotal bar, is situated on the proximal margin of the aperture, on the top of the large umbo. The ovicell is globular, deeply immersed with slightly perforated ectoecium.

Remarks. - As already noted by Sváček (1996), the type material has not been found within the museum's collection. It has not been found in any of the collections searched so far (Krahuklec Museum Eisenstadt, Austrian Geologishe Bundesanstalt, Vienna NHM, NM in Prague, MZM in Brno). Therefore we decided to erect a neotype for this species. Characteristic features are large umbo on middle of the frontal wall carrying avicularia, small umbos - spines (1-3) on the frontal wall and small areolar pores.

Occurrence. - Known only from the section Kralice nad Oslavou.
Infraorder Lepraliomorpha Gordon, 1989

Superfamily Schizoporelloidea Jullien, 1883

Family Schizoporellidae Jullien, 1883

\section{Genus Schizoporella Hincks, 1877}

\section{Schizoporella geminipora (Reuss, 1848)}

Figure 11A, B

$$
\begin{aligned}
& \text { v. * } 1848 \text { Vaginopora geminipora sp. n. - Reuss, p. 74, pl. 9, } \\
& \text { figs 3, } 4 \text {. } \\
& \text { v. } 1989 \text { Schizoporella geminipora (Reuss). - Schmid, p. 38, } \\
& \text { Pl. 11, figs 2-4. }
\end{aligned}
$$

Material. - 12 specimens (NM PM2-P 1369-PM2-P 1380).

Remarks. - The species is characteristically preserved as unilamellar colonies with a well developed dorsal side with large openings. According to Vávra (1984) this species probably grows on seagrass and the hole on dorsal side has been used for attaching the colony to the algal leaves.

Superfamily Smittinoidea Levinsen, 1909

Family Smittinidae Levinsen, 1909

\section{Genus Smittina Norman, 1903}

Smittina cervicornis (Pallas, 1766)

Figure 10F

1962 Porella cervicornis (Pallas). - Gautier, p. 204 [cum syn.]

1974 Porella cervicornis (Pallas). - David \& Pouyet, p. 194.

v. 1977 Porella cervicornis (Pallas). - Vávra, p. 139.

1989 Porella cervicornis (Pallas). - Schmid, p. 35, pl. 10, figs $1-3$.

v. 2001 Smittina cervicornis (Pallas). - Zágoršek, p. 55, pl. 18, figs 7, 9, 10

2002 Smittina cervicornis (Pallas). - Hayward \& McKinney, p. 49, fig. 22A-C.

v. 2003 Smittina cervicornis (Pallas). - Zágoršek, p. 163.

Material. - 10 specimens (NM PM2-P 1381-PM2-P 1390).

Remarks. - Widely distributed taxon from recent up to the Eocene, but usually with rarely developed ovicells (Zágoršek 2003). Specimens from Kralice however show deeply

Figure 10. Bryozoa. - A-C - Pyriporella loxopora (Reuss, 1848). A - general view showing chaotic arrangement of autozooecia, NM PM2-P 1327. B, C - detail showing small heterozooecia, NM PM2-P 1328. • D, E - Vibracella trapezoidea (Reuss, 1848). D - general view showing radial arrangement of autozooecia, NM PM2-P 1337. • E - V. trapezoidea (Reuss, 1848), detail showing ovicell and curved avicularia, NM PM2-P 1337. • F - Smittina cervicornis (Pallas, 1766), showing development of globular ovicells, NM PM2-P 1381. • G - Reteporella sp., NM PM2-P 1397. • H - Steginoporella cucullata (Reuss, 1848), NM PM2-P 1344. Length of scale bar $100 \mu \mathrm{m}$. 
Kamil Zágoršek et al. • The invertebrate fauna of the Middle Miocene (Lower Badenian) sediments of Kralice nad Oslavou
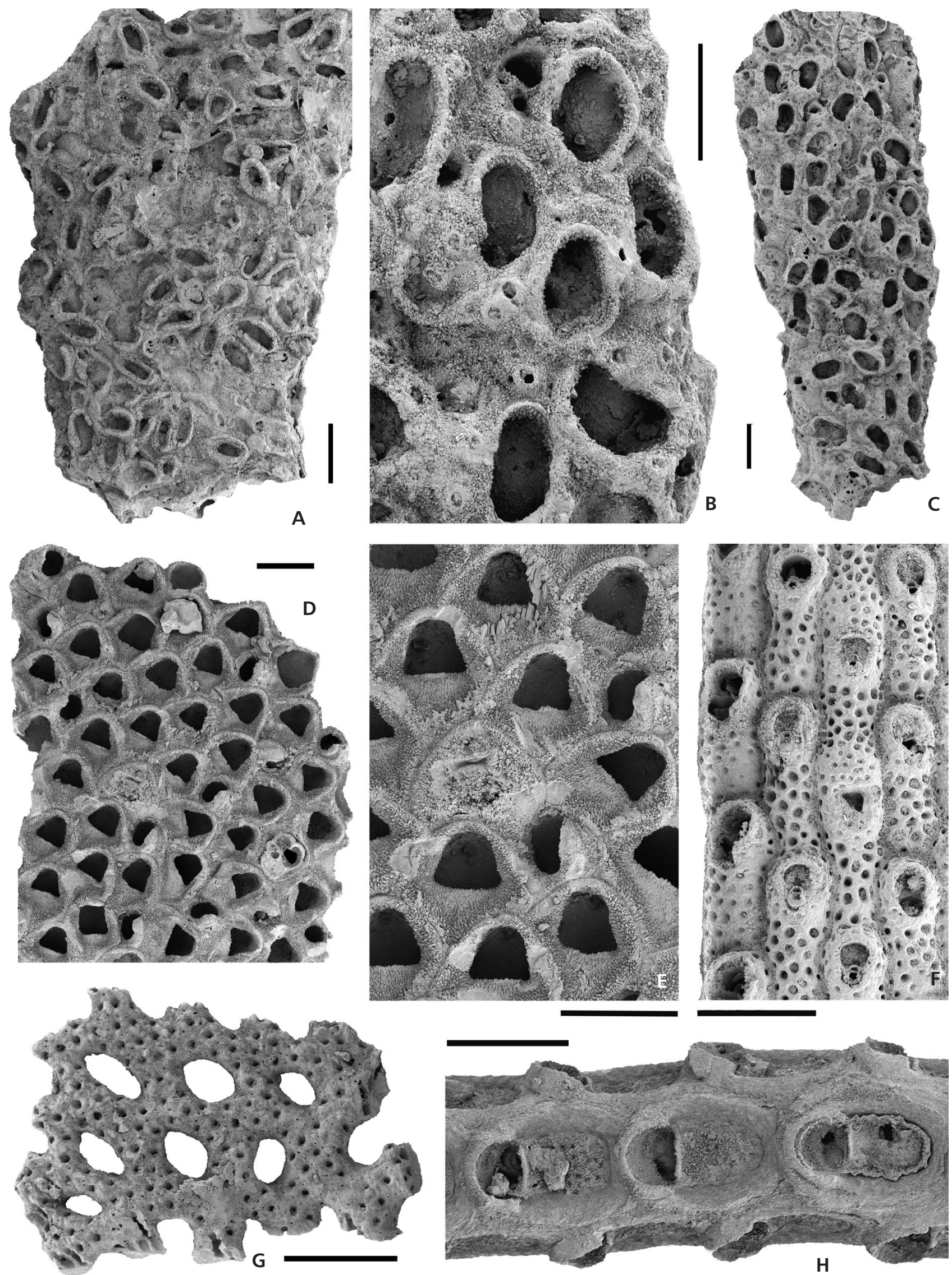
immersed ovicells with the frontal wall strongly perforated by large pseudopores. The ovicell has, up till now, not been illustrated from fossil material.

Superfamily Mamilloporoidea Canu \& Bassler, 1927

Family Ascosiidae Jullien, 1883

\section{Genus Kionidella Koschinsky, 1885}

\section{Kionidella moravicensis Procházka, 1893}

Figure $11 \mathrm{H}-\mathrm{J}$

* 1893 Kionidela moravicensis n. sp. - Procházka, p. 54, pl. 12, fig. 8a-d.

v. 1996 Kionidela moravicensis Procházka. - Sváček, p. 73, fig. 5 .

Material. - Neotype erected here NM PM2-P 1391 and 5 specimens (NM PM2-P 1392-PM2-P 1396).

Diagnosis. - The colonies are conical, with autozooecia budding in spiral. The autozooecia are globular, subhexagonal to oval. The aperture is eight-shaped, the proximal and distal part are oval, approximately equal in size and the condyles are arranged in the middle. The avicularia are large, circular to oval with pivot and usually arranged on one side of the aperture, ovicelled autozooecia rarely developed two avicularia. The ovicell is small, globular and deeply immersed with a strongly porous frontal wall.

Remarks. - The type material has not been found within the museum's collection (see remark on U. spinosa). K. moravicensis differs from K. excelsa Koschinsky, 1885 in size of the avicularia and ovicell, shape of autozooecia and aperture. K. excelsa developed smaller avicularia and ovicell with an almost nonporous frontal wall and the apertures have a much smaller proximal part than $K$. moravicensis. Moreover K. excelsa is known only from Early Tertiary sediments (Zágoršek 2003), while K. moravicensis occurs only in the Miocene (Vávra 1977).

Superfamily Celleporoidea Johnston, 1838

Family Phidoloporidae Gabb \& Horn, 1862

\section{Genus Reteporella Busk, 1884}

\section{Reteporella sp.}

Figure 10G

1767 Millepora cellulosa Linnaeus, 1767.

v. 1977 Sertella sp. - Vávra, p. 145.
? 1988 Sertella cellulosa Linne. - Moissette, p. 167. non 1933 Reteporella septentrionalis sp. n.; Harmer, p. 618.

Material. - 8 specimens (NM PM2-P 1397-PM2-P 1404).

Remarks. - Miocene specimens are often listed under the name M. cellulosa Linnaeus, 1767 (for example Moissette 1988). According to Harmer (1933) M. cellulosa is however not a valid species, because the name is pre-occupied by $M$. cellulosa Linnaeus, 1758, which is not a reteporellid bryozoan. Harmer (1933) also stated that M. cellulosa Linnaeus, 1767 is not definitely recognizable and therefore he erected the species Reteporella septentrionalis to replace it. He chose type specimens from the Reteporella cellulosa forma cellulosa described by Smitt (1868) and occurring in the Mediterranean. R. septentrionalis Harmer, 1933 however has narrower branches, smaller avicularia on the dorsal side and ovicells more immersed than in Miocene material. The Miocene specimens may be listed under the new name, but to solve the problem a revision of the Miocene species of genus Reteporella is needed. Therefore these specimens are listed under the formal name Reteporella sp.

Phylum Echinodermata Klein, 1734

Class Asteroidea de Blainville, 1830

\section{Asteroidea indet.}

Figure 12A-D

Material. - 372 isolated ossicles from samples KRAS-1-12 (NHMW 2008z0031/0001 to 0012, 2008z0032/0001, 0002).

Remarks. - Numerous asteroid ossicles occur throughout the Kralice section. The main bulk are marginal ossicles, ambulacral, adambulacral and abactinal plates are rare. Although most ossicles could not confidently be referred to specific asteroid groups, two taxa could be recognized among the material: Astropecten sp. and Goniasteridae indet. Marginal ossicles of Astropecten can be recognized by their oblique blocky shape, coarse, nodular ornamentation and presence of large tubercles. Goniasterid marginals, in contrast, feature a smooth surface with shallow pits and large articulation facets on the sides. No evidence of luidiid or asteriid ossicles co-occurring elsewhere in the basin (see Table 2 in Kroh 2007) could be found.

Class Crinoidea Miller, 1821

Crinoidea indet.

Figure 12E

Material. -1 isolated brachial ossicle from sample KRAS-11 (NHMW 2008z0030/0001). 

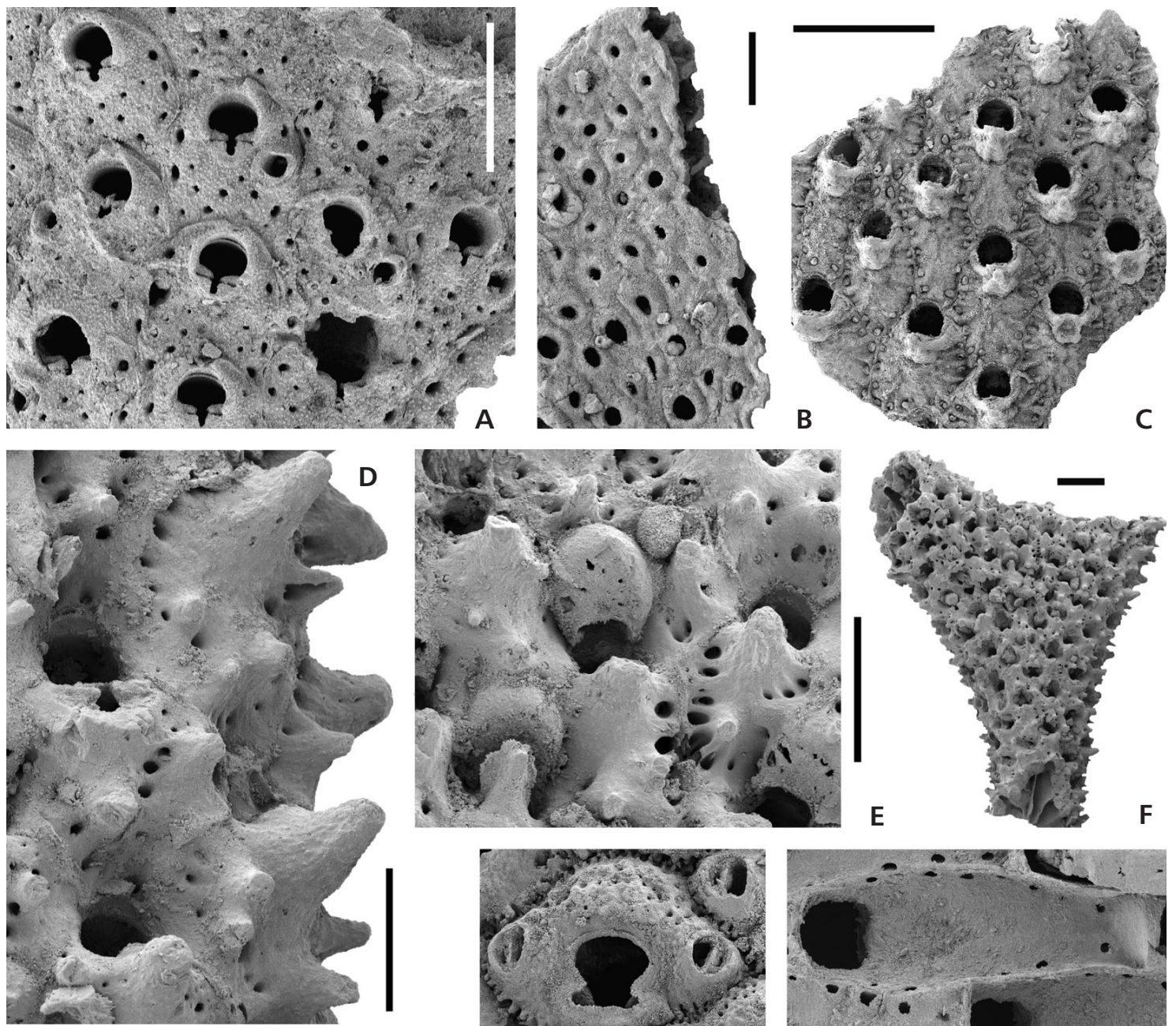

C

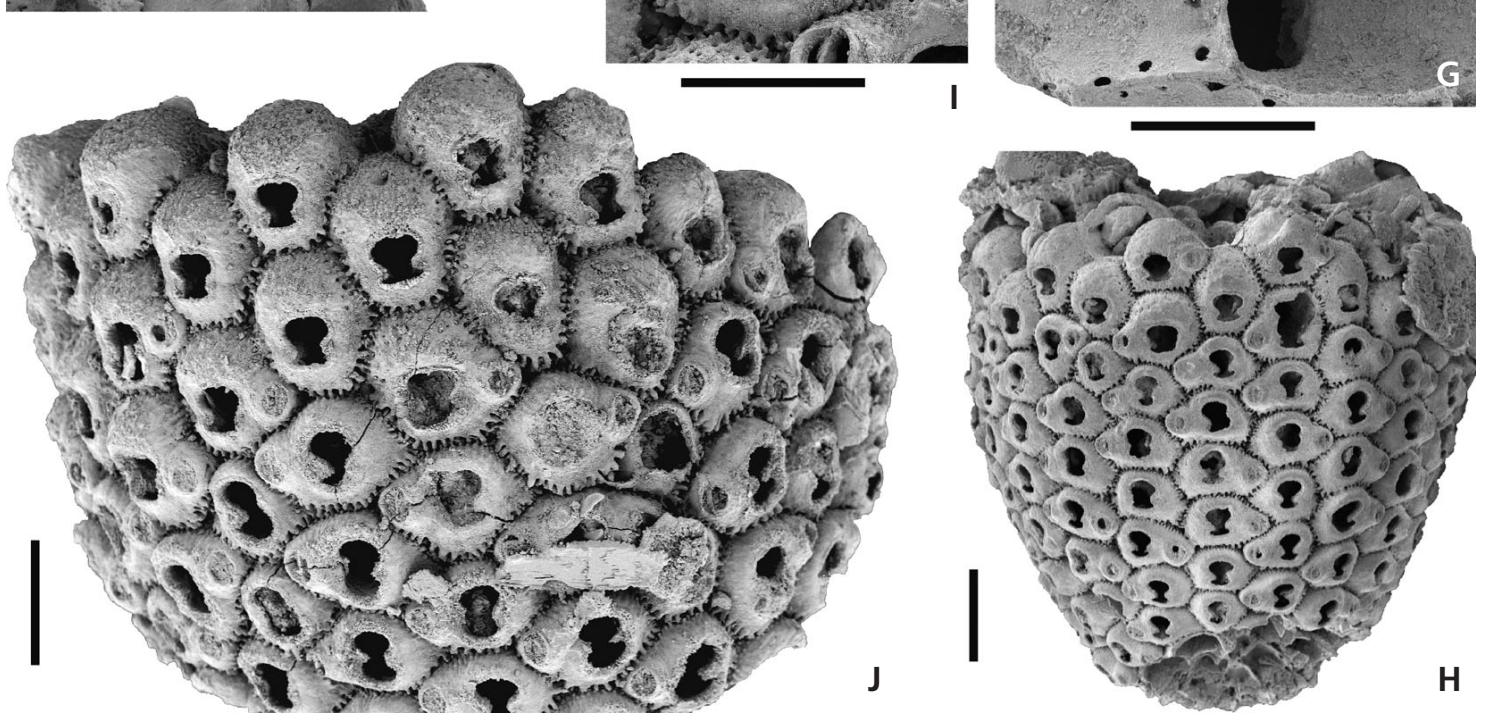

Figure 11. Bryozoa. • A, B - Schizoporella geminipora (Reuss, 1848). A - detail showing deep narrow sinus and circular avicularia, NM PM2-P 1369. B - dorsal side of the colony, NM PM2-P 1370. • C - Umbonula macrocheila (Reuss, 1848), showing characteristic large umbo situated proximally from the aperture, NM PM2-P 1350. D-G - Umbonula spinosa (Procházka, 1893). D - detail of neotype showing narrow central umbo and small additional umbos irregularly situated on the frontal wall, NM PM2-P 1354. E - detail of neotype showing ovicell with perforated ectoecium, NM PM2-P 1354. F - general view of the neotype, NM PM2-P 1354. G - reverse view of the autozooecia showing marginal areolar pore and umbonuloid frontal wall, NM PM2-P 1358. - H-J - Kionidella moravicensis Procházka, 1893. H - general view showing conical shape of the colony, NM PM2-P 1396. I - detail showing pair of avicularia and characteristic shape of aperture, NM PM2-P 1395. J - neotype showing development of ovicells, NMPM2-P 1391. Length of scale bar $100 \mu \mathrm{m}$. 
Remarks. - A single brachial was found among the other echinoderm material recovered from the bulk samples of the Kralice section. The scarcity of the material and undiagnostic nature of isolated crinoid brachials precludes any further identification.

Class Echinoidea Leske, 1778

\section{Echinoida indet.}

Material. - 26 fragmented demipyramids from samples KRAS-9 to 12 (NHMW 2008z0020/0001 to 0004).

Remarks. - Assigning isolated demipyramids is generally difficult, the poor preservation of the studied specimens made any attempt futile.

\section{Order Cidaroida Claus, 1880}

\section{Cidaroida indet.}

Figure 12H

Material. - 16 isolated abraded interambulacral plates from samples KRAS-5, 6, 9, 11, 12 (NHMW 2008z0017/0001 to $0005,2008 z 0033 / 0001) ; 6$ demipyramids from samples KRAS-6, 9, 10, 11 (NHMW 2008z0017/0006 to 0009).

Remarks. - The interambulacral plates bearing a single prominent tubercle subcentrally, clearly belong to cidaroids, but are badly weathered, thus precluding more refined identification. Most likely, they belong to Stylocidaris? polyacantha (Reuss 1860) according to the characteristic spine fragments which were isolated from the same samples. Additionally, some of the demipyramids found in the bulk samples can clearly be referred to the cidaroid type.

Family Cidaridae Gray, 1825

Stylocidaris? polyacantha (Reuss, 1860)

Figure $12 \mathrm{~F}, \mathrm{G}$

?1893 Dorocidaris papillata Leske. - Toula, p. 288.

?1893 Cidaris n. sp. - Toula, p. 288.
?1893 Cidaris pseudoserrata Cott. - Toula, p. 288.

?1893 Cidaris subularis d'Arch. - Toula, p. 288.

?1893 Ocellarplättchen des Scheitelschildes (Salenia?). Toula, p. 289.

?1981 Cidaris cidaris (L.). - Hamršmíd, p. 105, tab. 11.

?1981 C. rosaria Cott. - Hamršmíd, p. 105, tab. 11.

?1981 C. cf. belgica Cott. - Hamršmíd, p. 105, tab. 11.

?1981 C. cf. desmoulinsi Cott. - Hamršmíd, p. 105, tab. 11.

?1981 Porocidaris cf. schmidelii Cott. - Hamršmíd, p. 105, tab. 11.

?1981 Cidaris sp. - Hamršmíd, p. 105, tab. 11.

?1984 Cidaris sp. - Hamršmíd, p. 43, tab. 7.

2005 Stylocidaris? polyacantha (Reuss, 1860). - Kroh, pp. 2-4; pl. 1, figs 11-19; pl. 2, figs 1, 2; pl. 3, figs 1-16.

Material. - 38 primary spine fragments from samples KRAS-5, 6, K9, K10, 11 (NHMW 2008z0018/0001 to 0005, 2008z0033/0033, /0034).

Remarks. - Spine fragments of S.? polyacantha are quite characteristic and easily distinguished from most other cidaroids occurring in the Neogene of the Central Paratethys (Kroh 2005). The only species they can be confused with are spines of S.? schwabenaui, but the micro-sculpture of that species is coarser, consisting of bead-like nodulae rather than filigree thorns (see pls 2, 3 in Kroh 2005). Numerous cidaroid species have been recorded from Kralice by Toula (1893) and Hamršmíd (1981, 1984). Yet, only a single species could be confidently identified in the samples investigated. Most of the species recorded appear to be not very likely, as they refer to species restricted to the Eocene, respectively, Pliocene to Holocene elsewhere. Until shown otherwise, we prefer to follow Kroh (2005, pp. 13, 14), who regarded those records as doubtful and supposed that they were based on misidentifications.

Order Diadematoida Duncan, 1889

Family Diadematidae Peters, 1853

\section{Diadematidae indet.}

Figure $12 \mathrm{~J}-\mathrm{L}$

1893 Diadema Desori Reuss. - Toula, p. 289.

1981 Centrostephanus cf. calariensis Cott. - Hamršmíd, p. 105 , table 11 .

Figure 12. Echinodermata. $\bullet \mathrm{Aa}, \mathrm{Ab}-$ Goniasteridae indet. (marginal ossicle, NHMW 2008z0032/0001). $\bullet \mathrm{Ba}, \mathrm{Bb}-$ Astropecten sp. (marginal ossicle, NHMW 2008z0032/0002). - C - Astropecten? sp. (spine, NHMW 2008z0032/0006). - D - unidentified asteroid ambulacral ossicle (NHMW 2008z0032/0003) • E - unidentified crinoid brachial ossicle (NHMW 2008z0030/0001) • F, G - Stylocidaris? polyacantha (Reuss, 1860) (primary spine fragments, F - NHMW 2008z0033/0034, G - NHMW 2008z0033/0033). $\bullet$ H - cidaroid interambulacral plate (NHMW 2008z0033/0001) • I - Temnopleuroida juv. indet. (corona fragment, NHMW 2008z0033/0008) • J, L - Diadematidae indet. (interambulacral plates; NHMW 2008z0033/0005 to 0007). M-O - Schizechinus sp. (M - ambulacral plates, NHMW 2008z0033/0015; N - interambulacral plate fragment, NHMW 2008z0033/0015; O - rotula, NHMW 2008z0033/0015). • Pa-c - Echinocyamus transylvanicus Laube, 1869 (NHMW 2008z0033/0009). 


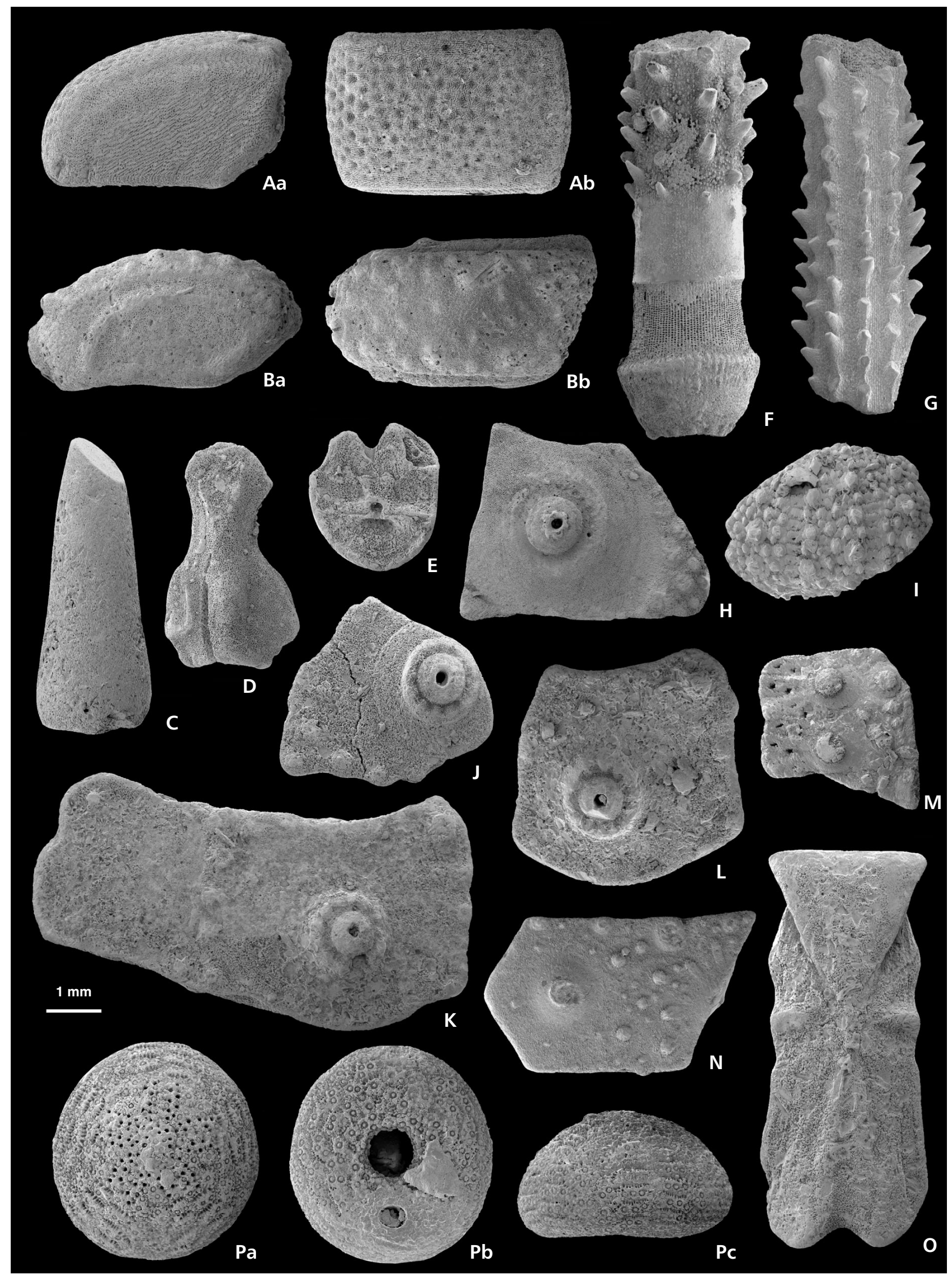


Material. - 30 interambulacral plates from samples KRAS-6, 7, 9, 10, 12 (NHMW 2008z0019/0001 to 0005, 2008z0033/0005 to 0007); 1 ambulacral plate from sample KRAS-9 (NHMW 2008z0019/0006).

Remarks. - Diadematoid coronal plates can be recognized by their characteristic perforate, crenulate primary tubercles which, in contrast to cidaroids, lack a well defined, sunken areole. The disarticulated and highly abraded nature of the material precludes assignment at a more refined taxonomic level. Primary spine fragments, usually common in sediments of this age, were surprisingly absent from the samples investigated.

Order Temnopleuroida Mortensen, 1941

Temnopleuroida juv. indet.

Figure 12I

?1981 Arbacina sp. Hamršmíd, p. 105, table 11.

?1981 Parasalenia cf. fontannesi Cott. - Hamršmíd, p. 105, table 11.

?1984 Parasalenia cf. fontannesi Cott. - Hamršmíd, p. 43, table 7.

Material. - 5 corona fragments from sample KRAS-9 (NHMW 2008z0021/0001, 2008z0033/0008).

Remarks. - Juvenile echinaceans are usually highly similar to each other and are notoriously difficult to identify, even when preserved in pristine condition. The present specimens are overgrown by syntaxial rim cement thus hiding most details of the tuberculation and microsculture. Based on the tubercle arrangement, the specimens might be tentatively referred to the genus Arbacina, but with a large degree of uncertainty.

Family Toxopneustidae Troschel, 1872

\section{Genus Schizechinus Pomel, 1869}

\section{Schizechinus sp.}

Figure 12M-O

?1981 Tripneustes? sp. - Hamršmíd, p. 105, tab. 11.
Material. - 2 ambulacral plates from samples KRAS-9, 10 (NHMW 2008z0022/0001, 2008z0033/0015); 9 interambulacral plates from samples KRAS-10 to 12 (NHMW 2008z0022/0002-0004, 2008z0033/0016); 5 rotulae from samples KRAS-9 to 11 (NHMW 2008z0022/0005 to 0007, 2008z0033/0017).

Remarks. - The rotulae of Schizechinus are very distinctive and cannot easily be confused with those of other Neogene echinoids of the Central Paratethys. The coronal plates are less characteristic and might be misidentified as Tripneustes, another common toxopneustid occurring in the region. The dense granular microsculpture in between the tubercles, however, is very typical and unique to Schizechinus (among the CP fauna).

Order Cassiduloida Claus, 1880

Family Echinolampadidae Gray, 1851

\section{Genus Echinolampas Gray, 1825}

Echinolampas? sp.

Figure 13B-D

Material. - 13 corona fragments from sample KRAS-9 (NHMW 2008z0023/0001, 2008z0033/0010 to 0012).

Remarks. - Cassiduloid corona fragments found in the bulk samples belong to two different groups, showing different tuberculation patterns. Fragments showing closely spaced tubercles and less massive coronal plates are most likely attributable to a juvenile or subadult Echinolampas.

\section{Genus Conolampas Agassiz, 1883}

\section{Conolampas sp.}

Fig. 13A

Material. - 5 corona fragments from samples KRAS-9, 10 (NHMW 2008z0024/0001, 2008z0033/0004).

Remarks. - The second type of cassiduloid coronal fragment is massive and shows wide-spread primary tubercles.

Figure 13. Echinodermata. • A - Conolampas sp. (interambulacral plate, NHMW 2008z0033/0004). B-D - Echinolampas? sp. (B - aboral corona fragment, NHMW 2008z0033/0010; C - fragment of peristomal margin, NHMW 2008z0033/0012; D - interambulacral plate, NHMW 2008z0033/0011). • E, Fa, Fb - Loveniidae indet. (aboral interambulacral corona fragments, NHMW 2008z0033/0013, 14). • G-K - Spatangoida indet. (G - petal fragment of Brissopsis? sp., NHMW 2008z0033/0023; H, I - interambulacral fragment with fasciole, NHMW 2008z0033/0018, ../0024; J - left anterior part of peristomal margin of Brissopsis? sp., NHMW 2008z0033/0025; K - aboral plate from the paired lateral interambulacra of Schizasteridae? indet., NHMW 2008z0033/0019). • L-O - Spatangus sp. (L - ambulacral plate from the periplastronal zones, NHMW 2008z0033/0031; M - aboral plate from the paired lateral interambulacra with distinctive tuberculation, NHMW 2008z0033/0030; N - adapical corona fragment with adapical petal IV, NHMW 2008z0033/0026; O - ambulacral plate from the frontal groove, NHMW 2008z0033/0032). P, Q - Clypeaster sp. (P - inside-view of interambulacral plate showing characteristic buttressing, NHMW 2008z0033/0002; Q - two ambulacral plates from the petals, NHMW 2008z0033/0003). 


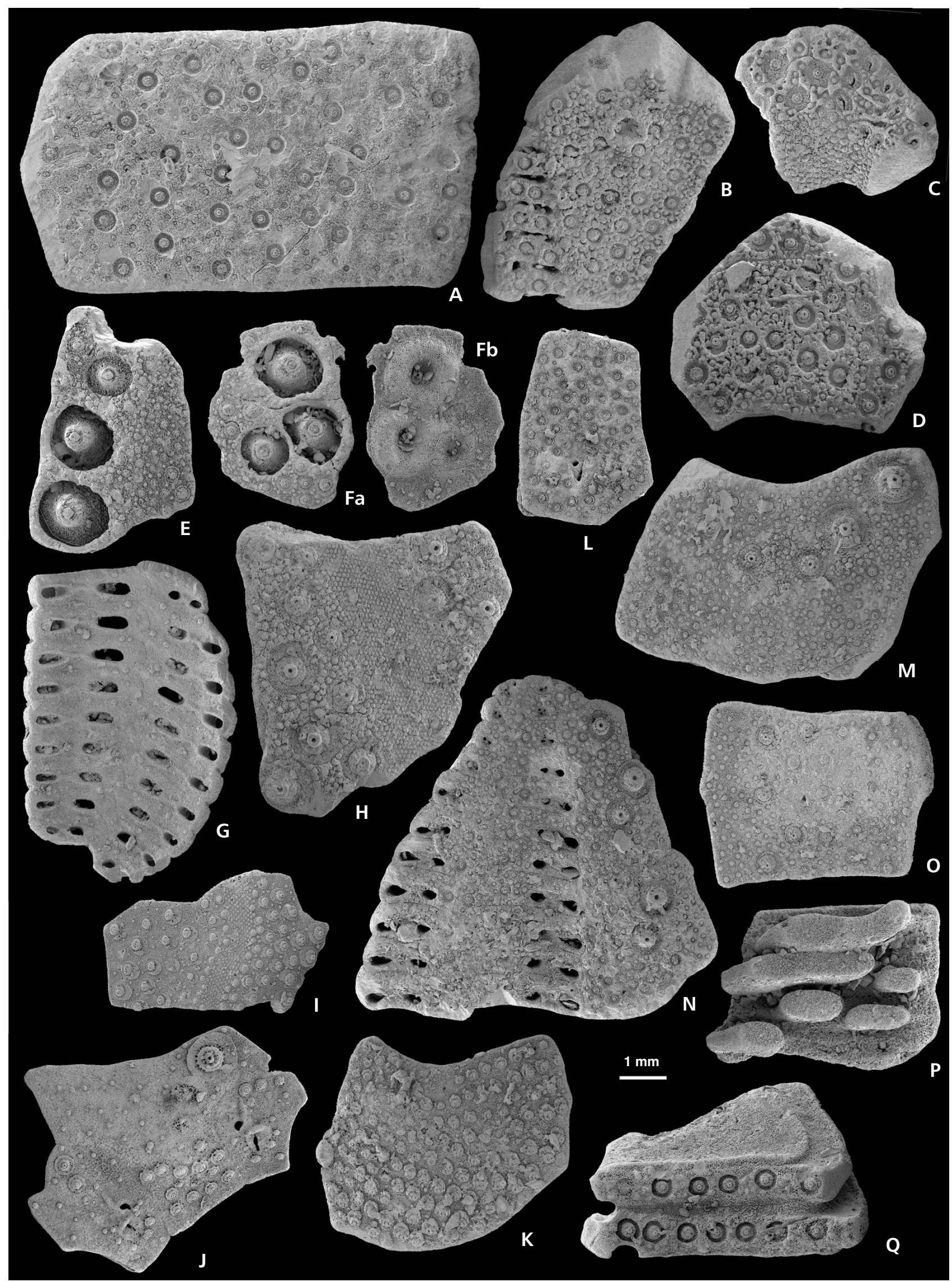


These features, together with the low curvature of the fragments, are characteristic of the large-sized cassiduloid Conolampas, common in the Early Badenian of the Central Paratethys.

Order Clypeasteroida Agassiz, 1872

Suborder Clypeasterina Agassiz, 1872

Family Clypeasteridae Agassiz, 1835

\section{Genus Clypeaster Lamarck, 1801}

\section{Clypeaster sp.}

Figure 13P, Q

1893 Clypeaster sp. - Toula, p. 288.

1981 Clypeaster sp. - Hamršmíd, p. 105, table 11.

Material. - 10 corona fragments from samples KRAS-9, 12 (NHMW 2008z0025/0001 to 0004, 2008z0033/0002-3).

Remarks. - Clypeasteroid fragments are easily recognized by their internal buttressing. The stout shape of the plates and pillars, as well as the form of the ambulacral pores indicated that the fragments belong to the genus Clypeaster. A scutelline origin can be excluded because of the lack of a microcanal system and stellate pillar arrangement.

Suborder Laganina Mortensen, 1948b

Family Fibulariidae Gray, 1855

\section{Genus Echinocyamus van Phelsum, 1774}

\section{Echinocyamus transylvanicus Laube, 1869}

Figure $12 \mathrm{~Pa}-\mathrm{C}$

1893 Echinocyamus sp. - Toula, p. 288

?1981 Echinocyamus pusillus (Mül.). - Hamršmíd, p. 105, tab. 11.

1984 Echinocyamus pusillus (Mül.). - Hamršmíd, p. 43, tab. 7.

2005 Echinocyamus transylvanicus Laube, 1869. - Kroh, pp. 77-79, figs 30 , 31.B, 32, 34.1; pl. 36, figs $1-5$; pl. 37 , figs $1-4$.

Material. - 59 specimens and fragments from samples KRAS-2, 3, 5 to 7 , and KRAS-9 to 12 (NHMW 2008z0026/0001 to 0009, 2008z0033/0009).

Remarks. - Differences between the species of Echinocyamus occurring in the Central Paratethys are slight (Kroh 2005). The Kralice material corresponds best with E. pseudopusillus and E. transylvanicus based on outline and periproct position. Consistently large height and subcircular outline favour identification as E. transylvanicus.

Order Spatangoida Claus, 1876

Spatangoida indet.

Figure 13G-K

?1893 Brissopsis sp. - Toula, pp. 288, 289.

?1981 Echinocardium sp. - Hamršmíd, p. 105, tab. 11.

?1981 Brissopsis sp. - Hamršmíd, p. 105, tab. 11.

1984 Irregularia indet. - Hamršmíd, p. 43, tab. 7.

Material. - 1144 test fragments from samples KRAS-1-12 (NHMW 2008z0027/0001 to 0012, 2008z0033/0018 to 0025).

Remarks. - Disarticulate spatangoid plates can be determined with surprising accuracy when the possible candidates are known and abundant comparative material is available. Not all plates, however, are equally diagnostic, precluding similarly refined identification for all parts of the corona. Due to the high morphological adaptation of the corona to a burrowing lifestyle in most spatangoid groups, many regions of the test are highly similar in tuberculation and plate shape. This holds particularly true for the ambital plates and the oral surface bearing the locomotory spines. Thus a large number of ossicles could not be attributed to an individual group within the Spatangoida. These are listed as Spatangoida indet. here, but do not represent a natural, monospecific grouping.

This collection of spatangoid coronal fragments and isolated plates contains remains of at least four, possibly more, different taxa. Groups represented by this "taxon" are Brissidae indet (?Brissopsis), Schizasteridae indet., Spatangus sp. and Loveniidae indet. The latter two are particularly characteristic and are discussed below.

Suborder Micrasterina Fischer, 1966

Family Spatangidae Gray, 1825

\section{Genus Spatangus Gray, 1825}

\section{Spatangus sp.}

Figure 13L-O

1893 Spatangus austriacus cf. Toula, p. 288.

1981 Spatangus sp. - Hamršmíd, p. 105, table 11.

Material. - 474 test fragments from samples KRAS-2, and KRAS-4 to KRAS-12 (NHMW 2008z0028/0001 to 0010, 2008z0033/0026 to 0032). 
Remarks. - Fragments of Spatangus can generally be quite easily distinguished from the co-occurring spatangoid remains by their robustness, characteristic tuberculation, and shape of the ambulacral pores. This holds particularly true for the plates of adapical interambulacra 1 to 4 , which bear characteristic enlarged tubercles arranged in chevronshaped groups, the plates from the petaloid region and the aboral part of the frontal groove

Family Loveniidae Lambert, 1905

\section{Loveniidae indet.}

Figure 13E, F

Material. - 11 test fragments from samples KRAS-2, 3, 7, 9, 10 (NHMW 2008z0029/0001-0004, 2008z0033/0013-14).

Remarks. - The presence of loveniids can be documented by plates bearing characteristic camellate tubercles, peculiar to this family. Other fragments of the loveniid test, however, are less easily recognized and are included in the group "Spatangoida indet.". Thus the abundance of the loveniids, based on test fragments bearing camellate tubercles, might be severely under-estimated in comparison to other echinoderm remains.

\section{Conclusions}

The detailed analysis of the different fossil groups and sedimentological study allows an interpretation of the age and development of palaeoenvironment in the southwestern part of the Carpathian Foredeep.

A study of the Bryozoan associations yielded 42 species, from which two species (K. moravicensis and $U$. spinosa) are endemic and occur only in the section Kralice III. Due to the absence of type material, neotypes of these species were established.

Section Kralice III can be well correlated with the Early Badenian time interval, characterized by the co-occurrence of the planktonic foraminiferal species $O$. suturalis and $G$. bisphericus. An Early Badenian age is also confirmed by molluscs assemblages. A massive occurrence of echinoderms and molluscs within a bryozoan event has been recorded for the first time in the Moravian part of the Carpathian Foredeep. A fully marine setting on the inner shelf is interpreted. A detailed study of the palaeoenvironment shows high variability in time and space. Shallow water, well aerated conditions with sea grass meadows prevailed, but were episodically displaced by deeper infralittoral conditions with low oxygen content in the sediment. Transported mollusc remains indicate a short distance from a rocky coastline. The sedimentation was in- fluenced by episodic storms or density currents. Variations in provenance, indicated by the change in the heavy mineral spectra are explained by varied basin geometry and input of volcanic material (distal airfall tephra).

Low nutrient and high oxygen contents can be concluded from the lower part of the profile. A relative increase in organic detritus content inside the sediment can be expected in the middle part of the profile. In the upper part of the profile suspension feeders dominate which may indicate a rich organic detritus content in the water column.

Interpretation is complicated by the predicted post-mortem transport, for which, however, positive evidence from taphonomical indicators is lacking.

\section{Acknowledgements}

The critical reviews of F. Rögl (NHM Vienna) and J. Scholz (Naturmuseum Senckenberg) are gratefully acknowledged. The study was supported by the projects GAČR 205/06/0637 and MSM0021620855, MSM 0021622412 and MK00002327201. Many thanks go also to N. Vávra from the Department of Palaeontology, Vienna University who supported us with fieldwork (through the project P19337-B17) and helpful comments on the paper. We gratefully acknowledge the help of G. Ribi from the Zoological Museum in Zürich who provided extant asteroid material for comparative studies. We express our sincere thanks to T. Třasoň, who helped us to collect samples.

\section{References}

BÁLDI, K. 2006. Paleoceanography and climate of the Badenian (Middle Miocene, 16.4-13.0 Ma) in the Central Paratethys based on foraminifera and stable isotope $\left(\delta^{18} \mathrm{O}\right.$ and $\left.\delta^{13} \mathrm{C}\right)$ evidence. International Journal of Earth Sciences 95, 119-142. DOI 10.1007/s00531-005-0019-9

Bagdasaryan, K.G., TATiShVili, K.G., KaZACHAShVILI, Z.R., MuschelishVILI, L.V., BADZOShVILI, C.I., ACHVELidiAni, E.G., ZhGenti, E.M., TAKTAKISHVILI, I.G. \& KVAliSHVILI, G.A. 1966. Spravochnik po ekologii morskich dvustvorok. 353 pp. Nauka, Moscow.

BERGgren, W.A., Kent, D.V., Swisher, C.C. \& Aubry, M.P. 1995. A revised Cenozoic geochronology and chronostratigraphy. SEPM 54, 129-212.

Bock, P. 2008. Bryozoan systematic. IBA web page, http://www.bryozoa.net/.

BRZÁK, M., HUBATKA, F. \& NEHYBA, S. 2001. Lower Badenian deposits near Kralice nad Oslavou (SW Moravia): results of geophysical, geomorphological and sedimentological research. Bulletin of the Czech Geological Survey 76(3), 149-154.

BRZOBOHATÝ, R. 1997. Paleobatymetrie spodního bádenu karpatské predhlubně na Moravě z pohledu otolitových faun, 37-45. In HLADILOVÁ, Š. (ed.) Dynamika vztahů marinního a kontinentálního prostředí. Masarykova univerzita, Brno.

BRZOBOHATÝ, R. 2001. Paleogeography, paleobiogeography and bathymetry based on fish, particularly otoliths. Berichte 
des Institutes für Geologie und Paläontologie der Karl-Franzens-Universitat Graz, Osterreich 4, 37-40.

CICHA, I., RÖGL, F., ČTYROKÁ, J., RUPP, C., BAJRAKTAREVIC, Z., BALdi, T., Bobrinskaya, O.G., DARAKChIEVA, S., Fuchs, R., Gagic, N., Gruzman, A.D., Halmai, J., KraShENINNIKOV, V.A., KALAC, K., KORECZ-LAKY, I., Krhovsky, J., LUCZKOWSKA, E., NAGY-GEllai, A., OlsZewsKa, B., POPESCU, G., REISER, H., SCHMID, M.E., SchreIber, O., SEROVA, M.Y., SzEGÖ, E., SZTRAKos, K., VENGLINSKYI, I.V. \& WENGER, W. 1998. Oligocene - Miocene Foraminifera of the Central Paratethys. Abhandlunged der Senckenbergian Naturforschung Gesellschaft 549, $1-325$.

DAVID, L. \& POUYET, S. 1974. Revision des Bryozoaires Cheilostomes miocenes du Bassin de Vienne (Austriche). Documents des Laboratoires Geologie Lyon 60, 83-257.

DAVIES, D.J., POWELL, E.N. \& STANTON, R.J. JR. 1989. Relative rates of shell dissolution and net sediment accumulation - a commentary: Can shell beds form by the gradual accumulation on biogenic debris on the sea floor? Lethaia 22, 207-212. DOI 10.1111/j.1502-3931.1989.tb01683.x

DEN DUlK, M., ReichardT, G.J., MEMON, G.M, Roelofs, E.M.P., ZACHARIASSE, W.J. \& VAN DER ZWAAN, G.J. 1998. Benthic foraminiferal response to variations in surface water productivity and oxygenation in the northern Arabian Sea. Marine Micropaleontology 35, 43-66. DOI 10.1016/S0377-8398(98)00015-2

DEN DUlK, M., REICHARDT, G.J., VAN HEYST, S., ZACHARIASSE, W.J. \& VAN DER ZWAAN, G.J. 2000. Benthic Foraminifera as proxies of organic matter flux and bottom water oxygenation? A case history from the northern Arabian Sea. Palaeogeography, Palaeoclimatology, Palaeoecology 161(3-4), 337-359. DOI 10.1016/S0031-0182(00)00074-2

FOLK, R.L. \& WARD, W. 1957. Brazos River bar: a study in the significance of grain-size parameters. Journal of Sedimentary Petrology 27, 3-26.

FORCE, E.R. 1980. The provenance of rutile. Journal of Sedimentary Petrology 50(2), 485-488.

GAUTIER, Y. 1962. Recherches écologiques sur les Bryozoaires Chilostomes en Méditeprande Occidentale. Recueil des travaux de la Station marine d'Endoume 38(24), 1-435.

GRILL, R. 1941. Stratigraphische Untersuchungen mit Hilfe von Mikrofaunen im Wiener Becken und den benachbarten Molasseanteilen. Öl und Kohle 37, 595-602.

HAMRŠMíD, B. 1981. Paleoekologická analýza faunistických společenstev terciérních sedimenti̊ lokality Kralice nad Oslavou. MSc. thesis, UJEP (MU) Brno.

HAMRŠMíD, B. 1984. Pokus o rekonstrukci podmínek sedimentace spodnobadenských usazenin v okolí Kralic nad Oslavou. Zemní plyn a nafta 29(1), 13-46.

HARMER, S.F. 1933. The genera of Reteporidae. Proceedings of the Zoological Society of London 1933, 615-627.

HARZHAUSER, M. \& PILlER, W.E. 2007. Benchmark data of a changing sea - Palaeogeography, palaebiogeography and events in the Central Paratethys during the Miocene. Palaeogeography, Palaeoclimatology, Palaeoecology 253, 8-31. DOI 10.1016/j.palaeo.2007.03.031

HAYWARD, P.J. \& MCKInNEY, F.K. 2002. Northern Adriatic Bryozoa from the vicinity of Rovinj, Croatia. Bulletin of the
American Museum of Natural History 270, 1-139. DOI 10.1206/0003-0090(2002)270<0001:NABFTV>2.0.CO;2

HAYWARD, P.J. \& RYLAND, J.S. 1998. Cheilostomatous Bryozoa Part I. Aeteoidea - Cribrilinoidea, 1-366. In BARNES, R.S. \& CROTHERS, J.H. (eds) Synopses of the British Fauna (New Series) 10. The Linnean Society, London.

HLADÍKOVÁ, J. \& HAMRŠMÍD, B. 1986. Isotopic composition of Lower Badenian fossils and sediments from the Carpathian Foredeep (SW Moravia, Czechoslovakia). $4^{\text {th }}$ Working meeting "Isotopes in Nature", Leipzig, 345-352.

HLADILOVÁ, Š., NEHYBA, S., DOLÁKOVÁ, N. \& HLADíKOVÁ, J. 1999. Comparison of some relics of Miocene sediments on the eastern margin of the Bohemian Massif. Geologica Carpathica 50, 31-33.

VAN HinsBergen, D.J.J., KOUWENHOVEN, T.J. \& VAN DER ZWAAN, G.J. 2005. Paleobathymetry in the backstripping procedure: Correction for oxygenation effects on depth estimates. Palaeogeography, Palaeoclimatology, Palaeoecology 221, 245-265. DO1 10.1016/j.palaeo.2005.02.013

HOHENEGGER, J. 2005. Estimation of environmental paleogradient values based on presence/absence data: a case study using benthic foraminifera for paleodepth estimation. Palaeogeography, Palaeoclimatology, Palaeoecology 217, 115-130. DOI 10.1016/j.palaeo.2004.11.020

Hohenegger, J., Coric, S., Khatun, M., Pervesler, P., RÖGL, F., RupP, C., SElge, A., UChMAN, A. \& WAGReich, M. 2007. Cyclostratigraphic dating in the Lower Badenian (Middle Miocene) of the Vienna Basin (Austria) - the Baden-Sooss core. International Journal of Earth Sciences. DOI 10.1007/s00531-007-0287-7.

HoLCOVÁ, K. 1996. Determination of transport of foraminiferal tests in the fossil record (South Slovakia Basin, Middle Miocene). Neues Jahrbuch für Geolologie und Paläontologie, Monatshefte 1996(4), 193-217.

HolcovÁ, K., ZÁGORŠEK, K., JAŠKOVÁ, V. \& LEHOTSKÝ, T. 2007. The oldest Miocene Bryozoa from the Carpathian Foredeep (boreholes Přemyslovice). Scripta Facultatis Scientiarum Naturalium Universitatis Masarykianae Brunensis, Geology $36,47-55$.

HolCOVÁ, K. \& ZÁGORŠEK, K. 2008. Bryozoa, foraminifera and calcareous nannoplankton as environmental proxies of the "bryozoan event" in the Middle Miocene of the Central Paratethys (Czech Republic). Palaeogeography, Palaeoclimatology, Palaeoecology 267(3), 216-234.

DOI 10.1016/j.palaeo.2008.06.019

HUBERT, J.F. 1962. A zircon-tourmaline-rutile maturity index and the interdepence of the composition of heavy mineral assemblages with the gross composition and texture of sandstones. Journal of Sedimentary Petrology 32(3), 440-450.

ILGAR, A. \& NEMEC, W. 2005. Early Miocene lacustrine deposits and sequence stratigraphy of the Ermenek Basin, Central Taurides, Turkey. Sedimentary Geology 173, 233-275. DOI 10.1016/j.sedgeo.2003.07.007

JANOSCHEK, R. 1937. Die Moldaviten in Mähren, 329-356. In SUESS, F.E. (ed.) Festschrift der Geologischen Gesellschaft in Wien, Mitteilungen 29. Wien.

JORISSEN, F.J., DE STIGTER, H.C. \& WidMARK, J.G.V. 1995. A conceptual model explaining benthic foraminifera microha- 
bitat. Marine Micropaleontology 26, 3-15.

DOI $10.1016 / 0377-8398(95) 00047-X$

KAIHO, K. 1994. Benthic foraminiferal dissolved-oxygen index and dissolved oxygen levels in the modern ocean. Geology 22, 719-722.

DOI 10.1130/0091-7613(1994)022<0719:BFDOIA $>2.3 . C O ; 2$

KAIHO, K. 1999. Effect of organic carbon flux and dissolved oxygen on the benthic foraminiferal oxygen index (BFOI). $M a$ rine Micropaleontology 37, 67-76.

DO1 10.1016/S0377-8398(99)00008-0

KIDWELL, S. M. 1986. Taphonomic Feedback in Miocene Assemblages: Testing the Role of Dead Hardparts in Benthic Communities. Palaios 1, 239-255. DOI 10.2307/3514688

KIDWELL, S.M. \& BosenCE, D.W.J. 1991. Taphonomy and Time-Averaging of Marine Shelly Faunas. Topics in Geobiology 9, 115-210.

KOUTEK, J. 1971. Relikty třetihorních usazenin v širším okolí Třebíče. Sborník Přirodovědného klubu Západomoravského muzea v Třebiči 8, 37-46.

Kouwenhoven, T.J., HILGEN, F.J. \& VAN DER ZwAAN, G.J. 2003. Late Tortonian - Early Messinian stepwise disruption of the Mediterranean-Atlantic connections: constraints from benthic foraminiferal and geochemical data. Palaeogeography, Palaeoclimatology, Palaeoecology 198(3/4), 303-319. DO1 10.1016/S0031-0182(03)00472-3

$\mathrm{KROH}$, A. 2003. The Echinodermata of the Langhian (Lower Badenian) of the Molasse Zone and the northern Vienna Basin (Austria). Annalen des Naturhistorischen Museums in Wien, Serie A 104, 155-183.

KroH, A. 2005. Catalogus Fossilium Austriae. Band 2. Echinoidea neogenica. 210 pp. Österreichische Akademie der Wissenschaften, Wien.

KROH, A. 2007. Climate changes in the Early to Middle Miocene of the Central Paratethys and the origin of its echinoderm fauna. Palaeogeography, Palaeoclimatology, Palaeoecology 253, 185-223. DOI 10.1016/j.palaeo.2007.03.039

LiHou, J.C. \& MANGE-RAJETZKY, M.A. 1996. Provenance of the Sardona Flysch, eastern Swiss Alps: example of high-resolution heavy mineral analysis applied to an ultrastable assemblage. Sedimentary Geology 105, 141-157. DOI 10.1016/0037-0738(95)00147-6

MANDIC, O., HARZHAUSER, M., SPEZZAFERRI, S. \& ZUSCHIN, M. 2002. The paleoenvironment of an early Middle Miocene Paratethys sequence in NE Austria with special emphasis on paleoecology of mollusks and foraminifera. Géobios, Mémoire spéciale 24, 193-206.

MANDIC, O. \& HARZHAUSER, M. 2003. Molluscs from the Badenian (Middle Miocene) of the Gaindorf Formation (Alpine Molasse Basin, NE Austria) - Taxonomy, Paleoecology and Biostratigraphy. Annales des Naturhistorische Museum in Wien, Serie A 104, 85-127.

MANDIC, O. 2004. Pectinid bivalves from the Grund Formation (Lower Badenian, Middle Miocene, Alpine-Carpathian Foredeep) - taxonomic revision and stratigraphic significance. Geologica Carpathica 55(2), 129-146.

MCKINNEY, F.K. \& JACKSON, J.B.C. 1989. Bryozoan Evolution. 238 pp. Unwin Hyman, Boston.

MísǍ̆, Z. 1993. Vysvětlivky k základní geologické mapě ČR list 24-31 Velké Meziř̌ičí. Česká geologická služba, Praha.
Moissette, P. 1988. Faunes de Bryozoaires du Messinien d'Algerie Occidentale. Documents des Laboratoires Geologie Lyon 102, 1-351.

MORTON, A.C. 1991. Geochemical studies of detrital heavy minerals and their application to provenance research. Geological Society Special Publication 57, 31-45.

MorTON, A.C. \& HALlsworTh, C. 1994. Identifying-provenance-specific features of detrital heavy mineral assemblages in sandstones. Sedimentary Geology 90, 241-256. DOI 10.1016/0037-0738(94)90041-8

MURRAY, J.W. 1991. Ecology and paleoecology of benthic Foraminifera. 397 pp. Longman Scientific \& Technical, London.

NeHYBA, S. 1997. Miocene Volcaniclastics of the Carpathian Foredeep in the Czech Republic. Věstník Českého geologického ústavu 72(4), 311-327.

NEHYBA, S. 2003. Př́spěvek k poznání neogenních sedimentů v okolí Kralic na Oslavou a Březníka. Acta Musei Moraviae, Scientiae geologicae 88, 177-190.

NehybA, S. \& RoetZel, R. 1999. Lower Miocene Volcaniclastics in Southwestern Moravia and Lower Austria. Jahrbuch der Geologischen Bundesanstalt 141(4), 473-490.

NEHYBA, S. \& STRÁNíK, Z. 2005. Vulkanoklastika v pavlovickém souvrství ždánické jednotky. Geologické výzkumy na Moravě a ve Slezsku v roce 2004 12(1), 37-41.

NEMEC, W. 1990. Aspects of sediment movement on steep delta slopes. Association of Sedimentology Special Publication 10, 29-73.

PAPP, A. \& TURnOvsKy, K. 1953. Die Entwicklung der Uvigerinen im Vindobon (Helvet und Torton) des Wiener Beckens. Jahrbuch der Geologischen Bundesanstalt Wien 96, 117-142.

POLDERVAART, A. 1950. Statistical studies of zircon as a criterion in granitization. Nature 165, 574-575.

DOI $10.1038 / 165574 b 0$

PoUYET, S. 1997. Les Bryozoaires du Badénien (Miocéne moyen) d'Olimpow (Pologne). Documents des Laboratoires de Géologie de Lyon 145, 1-125.

PROCHÁZKA, V.J. 1893. Miocén kralický u Náměště na Moravě. Věstník Královské České společnosti nauk, Třída mathematicko-přirodovědná 6, 1-84.

PUPIN, J.P. 1980. Zircon and granite petrology. Contribution to Mineralogy and Petrology 73, 207-220.

DOI $10.1007 / \mathrm{BF} 00381441$

PUPIN, J.P. 1985. Magmatic zonic of hercynian granitoids in France based on zircon typology. Schweitzerische Mineralogische und Petrographische Mitteilungen 65, 29-56.

REDINGER, J. 1990. Bolboformaceae (Protophyta, incertae sedis) in Miozän der Karpatischen Vortiefe in Mähren und im tschechoslowakischen Teil des Wiener Beckens. Annalen des Naturhistorischen Museums in Wien, Serie A 94, 15-22.

REUSS, A.E. 1848. Die fossilen Polyparien des Wiener Tertiärbeckens. Ein monographischer Versuch. Naturwissenschaftiche Abhandlungen 2(1), 1-109.

RöGL, F. 1986. Late Oligocene and Miocene planktic foraminifera of the Central Paratethys, 315-328. In BoLLI, H.M., Saunders, J.B. \& PerCh-Nielsen, K. (eds) Planktonic stratigraphy. Cambridge University Press.

SCOTT, E.D., BoumA, A.H. \& BRYANT, W.R. 2004. Siltstones, mudstones and shales: Depositional processes and characteris- 
tics. Society For Sedimentary Geology, Special Publication, 4-8.

Sen-Gupta, B.K. \& Machain-Castillo, M.L. 1993. Benthic foraminifera in oxygen-poor habitats. Marine Micropaleontology 20, 183-201. DOI 10.1016/0377-8398(93)90032-S

SCHMID, B. 1989. Cheilostome Bryozoen aus dem Badenien (Miozan) von Nussdorf (Wien). Beiträge zur Paläontologie von Österreich 15, 1-101.

SCHUltZ, O. 2001. Catalogus Fossilium Austriae. Band 1. Bivalvia neogenica (Nuculacea-Unionacea). 379 pp. Österreichische Akademie der Wissenschaften, Wien

SMITT, F.A. 1868. Bryozoa marina in regionibus arcticis et borealibus viventia recensuit. Öfversigt af Kongliga Vetenskaps-Akademiens Förhandlingar 24, 443-487.

SPEZZAFERRI, S., ĆORIĆ, S., HOHENEGGER, J. \& RÖGL, F. 2002. Basin-scale paleobiogeography and paleoecology: an example from Karpatian (Latest Burdigalian) benthic and planktonic foraminifera and calcareous nannofossils from the Central Paratethys. Geobios 35 241-256. DOI 10.1016/S0016-6995(02)00063-3

SPEZZAFERRI, S., RÖGL, F., ĆORIĆ, S. \& HOHENEGGER, J. 2004. Paleoenvironmental changes and agglutinated foraminifera across the Karpatian/Badenian (Early/Middle Miocene) boundary in the Styrian Basin (Austria, Central Paratethys). Grzybowski Foundation Special Publication 8, 423-459.

Steininger, F., Schultz, O., Stojaspal, F., BOHN-HaVAs, M., KOCHANSKY, V., KÓKAY, J., KOJUMdGIEVA, E., KRACH, W., Muldini-MAmuZic, S., NevessKaya, A., OndReJIČKOVÁ, A. \& ŠVAGROVSKÝ, J. 1978. Die Molluskenfauna des Badenien, 327-404. In PAPP, A., CICHA, I., SENEŠ, J. \& STEININGER, F. (eds) Chronostratigraphie und Neostratotypen, Miozän der Zentralen Paratethys. VI, M4 Badenien (Moravien, Wielicien, Kosovien). VEDA, Bratislava.

StudencKA, B. 1986. Bivalves from the Badenian (Middle Miocene) marine sandy facies of Southern Poland. Palaeontologica Polonica 47, 1-128.

StudencKa, B., GonTSharova, I.A. \& Popov, S.V. 1998. The bivalve faunas as a basis for reconstruction of the Middle Miocene history of the Paratethys. Acta Geologica Polonica 48(3), $285-342$.

SVÁČEK, P. 1995. Lower Badenian Bryozoa of the South Moravian part of the Carpathian Foredeep. 142 pp. Unpublished MSc thesis, Masaryk University Brno.

SVÁČEK, P. 1996. Lower Badenian Bryozoa in the South Moravian part of the Carpathian Foredeep. Geologické výzkumy na Moravě a ve Slezsku 1995, 72-73.

TAYLOR, P.D. \& MCKInNEY, F.K. 2006. Cretaceous Bryozoa from the Campanian and Maastrichtian of the Atlantic and Gulf Coastal Plains, United States. Scripta Geologica 132, $1-346$.

ToulA, F. 1893. Die Miocänablagerungen von Kralitz im Mähren. Anales des Naturhofmuseums 2, 1-11.

TRIEBOLD, S., VON EYNATTEN, H. \& ZACK, T. 2005. Trace elements in detrital rutile as provenance indicators: a case study from the Erzgebirge, Germany. Schriftenreihe der Deutschen Gesellschaft für Geowissenschaften 38, 44-145.

TŘASOŇ, T. 2005. Foraminiferová společenství lokality Kralice nad Oslavou (baden, karpatská předhlubeř). Unpublished MSc thesis, Charles University Prague.
VÁVRA, N. 1977. Catalogus Fossilium Austriae. Heft Vb/3. Bryozoa tertiaria. 189 pp. Österreichische Akademie der Wissenschaften, Wien.

VÁVRA, N. 1984. A littoral bryozoan assemblage from the Korytnica Clays (Middle Miocene, Holy Cross Mountains, Central Poland). Acta Geologica Polonica 34, 223-237.

ZABALA, M. \& MALUQUER, P. 1988. Illustrated keys for the classification of Mediterranean Bryozoa. Treballs del Museu de Zoologia 4, 1-294.

ZACK, T., von Eynatten, H. \& KronZ, A. 2004a. Rutile geochemistry and its potential use in quantitative provenance studies. Sedimentary Geology 171, 37-58.

DOI 10.1016/j.sedgeo.2004.05.009

ZACK, T., Moraes, R. \& KRONZ, A. 2004b. Temperature dependence of $\mathrm{Zr}$ in rutile: empirical calibration of a rutile thermometer. Contribution to Mineralogy and Petrology 148, 471-488.

ZÁGORŠEK, K. 2001. Eocene Bryozoa from Hungary (part II. Systematic Paleontology). Courier Forschungsinstitut Senckenberg 231, 19-159.

ZÁGORŠEK, K. 2003. Eocene Bryozoa from Waschberg Zone (Austria). Beiträge zur Paläontologie 28, 101-263.

ZÁGORŠEK, K. \& HOLCOVÁ, K. 2003. Mechovkami bohaté třetihorní sedimenty jižní Moravy. Sborník vědeckých prací Vysoké školy báňské Technické univerzity Ostrava, Řada hornicko-geologická 49, 81-83.

ZÁGORŠEK, K. \& HOLCOVÁ, K. 2005. A bryozoan and foraminifera association from the Miocene of Podbrezice, south Moravia (Czech Republic): an environmental history, 383-396. In MOYANO, H.G., CANCINO, J.M. \& WYSE JACKSON, P.N. (eds) Bryozoan Studies 2004. Taylor \& Francis, London.

ZÁGORŠEK, K. \& VÁVRA, N. 2007. Bryozoan fauna from Steinebrunn (Lower Austria, Badenian) - a revision to establish a basis for comparisons with Moravian faunas. Scripta Facultatis Scientae Naturalis Universitatis Masarykensis Brunensis, Geology 36, 65-72.

ZÁGORŠEK, K., HolCOVÁ, K. \& VÁVRA, N. 2004. Bryozoans localities from the Moravian part of Vienna Basin (preliminary results). Scripta Facultatis Scientiarum Naturalium Universitatis Masarykianae Brunensis, Geology 31-32, 35-46.

ZÁGORŠEK, K., HOLCOVÁ, K. \& TŘASOŇ, T. 2007a. Bryozoan event from Middle Miocene (Early Badenian) lower neritic sediments from the locality Kralice nad Oslavou (Central Paratethys, Moravian part of the Carpathian Foredeep). International Journal of Earth Sciences (Geologische Rundschau). DOI 10.1007/s00531-007-0189-8.

ZÁGORŠEK, K., VÁVRA, N. \& HOLCOVÁ, K. 2007b. New and unusual Bryozoa from the Badenian (Middle Miocene) of the Moravian part of the Vienna Basin (Central Paratethys, Czech Republic). Neues Jahrbuch fur Geologie and Paläontologie 243/2, 201-215. DO1 10.1127/0077-7749/2007/0243-0201

VAN DER ZWAAN, G.J., JORISSEN, F.J. \& DE STIGTER, H.C. 1990. The depth dependency of planktonic/benthic foraminiferal ratios: constraints and applications. Marine Geology 95, 1-16. DOI 10.1016/0025-3227(90)90016-D

ZIMMERLE, W. 1979. Accessory Zircon from Rhyolite, Yellowstone National Park (Wyoming, U.S.A.) Zeitschrift der Deutschen Geologischen Gesellschaft 130, 361-369. 


\section{Appendix A. Abundance data and specimen counts of Foraminifera and Nannoplankton for section Kralice III.}

\begin{tabular}{|c|c|c|c|c|c|c|c|c|c|c|c|c|}
\hline Bentic foraminifera & KRAS-1 & KRAS-2 & KRAS-3 & KRAS-4 & KRAS-5 & KRAS-6 & KRAS-7 & KRAS-8 & KRAS-9 & \multicolumn{3}{|c|}{ KRAS-10KRAS-11KRAS-12 } \\
\hline Alabamina sp. & 0.8 & 1.4 & & & & & & & 0.4 & 1 & & \\
\hline Ammonia beccarii (Linne) & & & & & & & 0.5 & & & & & \\
\hline Amphicoryna badenensis (d'Orbigny) & 1.5 & & & & & 0.5 & & & & & & \\
\hline Amphistegina bohdanowiczi Bieda & & 0.4 & & & & & & & & & & \\
\hline Angulogerina angulosa (Williamson) & & & & & 1.9 & & & 1.9 & 0.5 & & & \\
\hline Asterigerinata planorbis (d'Orbigny) & 14.7 & 15.5 & 13.5 & 9 & 6.2 & 5.5 & 13.7 & 11.4 & 6 & 5.4 & 15 & 7.7 \\
\hline Baggina sp. & 1 & & & & 0.5 & & & & & & & \\
\hline Bolivina antiqua d'Orbigny & & & 1.8 & & & 0.9 & 1 & & 0.5 & & & \\
\hline Bolivina dilatata dilatata Reuss & 1 & 2.6 & 1.3 & 1.4 & 6.7 & 4.1 & & 2.4 & 0.5 & 0.7 & & 0.6 \\
\hline Bolivina hebes Macfadyen & & & 1.3 & 0.5 & 1.4 & 3.2 & 0.5 & 0.5 & & & & \\
\hline Bolivina plicatella Cushman & 0.5 & 3 & 0.3 & 1.9 & & & & & 2 & & & \\
\hline Bolivina pokornyi Cicha \& Zapletalova & & & 0.5 & 0.9 & & 1.4 & & & & & & \\
\hline Bolivina scalprata retiformis Cushman & & 0.5 & & & & & & & & & & \\
\hline Bolivina viennensis Marks & & & & 1.2 & 0.5 & & & & & & & \\
\hline Bulimina buchiana d'Orbigny & 2 & & & & & & & & & & & \\
\hline Bulimina elongata d'Orbigny & & 2.6 & 2.2 & 4.3 & 4.8 & 5.5 & 0.5 & & & & & \\
\hline Bulimina striata d'Orbigny & 3.6 & 0.4 & & & & 6 & 0.5 & & & & & \\
\hline Bulimina subulata Cushman \& Parker & & & & & 0.7 & 1.5 & & & & & & \\
\hline Cancris auriculus (Fichtel \& Moll) & & 0.4 & & & 0.5 & & & 0.5 & & & & \\
\hline Cassidulina laevigata d'Orbigny & 1 & 2.1 & & 9 & 3.3 & 2.8 & 0.5 & 1 & 0.5 & & 0.8 & \\
\hline Cibicidoides sp. (small-sized) & 11.7 & 9 & 13 & 13.3 & 10 & 22.1 & 22.4 & 40 & 32.8 & 60.1 & 29.1 & 62.2 \\
\hline Cibicidoides ungerianus (d'Orbigny) & 0.5 & 0.4 & 1.8 & 1.9 & 4.3 & 1.8 & 9.8 & 2.9 & 8 & 0.7 & 13.4 & 5.8 \\
\hline Elphidium fichtellianum (d'Orbigny) & 1.5 & 2.1 & & & 2.4 & 2.3 & 2.9 & 2.4 & 0.5 & 2 & 1.6 & 3.8 \\
\hline Elphidium flexuosum (d'Orbigny) & 3 & 4.3 & & & 4.3 & & & 6.2 & 2.5 & & & 1.3 \\
\hline Elphidium macellum Fichtel \& Moll & 0.5 & 0.9 & 0.9 & & & & 2 & & & & & \\
\hline Elphidium rugosum (d'Orbigny) & & & 2.7 & 0.5 & & & & & & & & \\
\hline Elphidium sp. (juvenile) & & & & 6.6 & & 0.5 & & & & & & \\
\hline Eponides repandus (Fichtel \& Moll) & & & & & & & & & & & 0.8 & \\
\hline Fursenkoina acuta (d'Orbigny) & & & & 0.5 & 1.9 & & & & & & & \\
\hline Globocassidulina oblonga (Reuss) & 5 & 1.3 & 2.7 & 1.9 & 1 & 3.2 & 0.5 & & 0.5 & 0.7 & 0.8 & \\
\hline Hansenisca soldanii (d'Orbigny) & & & 0.5 & 3.3 & 1.4 & 1.8 & 0.5 & 0.5 & 0.5 & 0.7 & 0.8 & 0.6 \\
\hline Hanzawaia boueana (d'Orbigny) & 4 & 9.4 & 5.4 & 11.4 & 10.5 & 9.7 & 6.3 & 2.4 & 0.5 & 0.7 & 0.8 & \\
\hline Heterolepa dutemplei (d'Orbigny) & 5.1 & 1.3 & 2.2 & 0.9 & 1.4 & 4.1 & 2.4 & 1 & 2.5 & 4.7 & 10.2 & 3.8 \\
\hline Karreriella chilostoma (Reuss) & & & 0.5 & & & & & & & & 0.8 & \\
\hline Lagena striata (d'Orbigny) & & & & & & & & 0.5 & 1 & & & \\
\hline Lagena hexagona & & 0.4 & & & 0.5 & 0.5 & & & & & & \\
\hline Lapugyina schmidi Popescu & & & & 0.5 & & & & & & & & \\
\hline Lenticulina sp. (broken or abraded) & & & & & & & & & & 13.5 & 3.2 & \\
\hline Lenticulina sp. (juvenile) & & 0.5 & 1.3 & 0.5 & & 0.5 & 1 & 0.5 & & & & \\
\hline Lobatula lobatula (Walker \& Jacob) & 22.8 & 14.6 & 18.4 & 5.2 & 7.1 & 8.3 & 23.9 & 17.1 & 26.9 & 2 & 10.2 & 5.8 \\
\hline Marginulina hirsuta d'Orbigny & & & 0.9 & 0.9 & & & 0.5 & & & & & \\
\hline Melonis pompiloides (d'Orbigny) & & 1.3 & 1.8 & 2.8 & 2.9 & 1.4 & & 3.8 & 1.5 & & 2.4 & 3.2 \\
\hline Nonion commune (d'Orbigny) & 7.6 & 12.9 & 16.1 & 10 & 11.9 & 6.9 & 4.9 & 0.5 & 3.5 & 0.7 & 3.2 & 0.6 \\
\hline Nonion sp. & 0.5 & & & 0.5 & & & & & & & & 1.3 \\
\hline Nummoloculina contraria (d'Orbigny) & & & & 1.4 & & & & & & & & \\
\hline Pararotalia aculeata (d'Orbigny) & & 0.9 & 0.5 & 0.9 & & & 0.5 & 0.5 & 1.5 & & 0.8 & \\
\hline Planostegina costata (d'Orbigny) & & & & & & & & & & 3.4 & 0.8 & \\
\hline $\begin{array}{l}\text { Plectofrondicularia digitalis } \\
\text { (Neugeboren) }\end{array}$ & 1.5 & & 1.3 & 1.9 & 5.2 & 1.8 & & & & 0.7 & & \\
\hline Porosolenia sp. & 1.5 & 0.5 & 1.3 & & 1 & 0.5 & & & 2 & & & \\
\hline Porosononion granosum (d'Orbigny) & & 0.9 & & & 1 & & 1 & & & & & \\
\hline
\end{tabular}




\begin{tabular}{|c|c|c|c|c|c|c|c|c|c|c|c|c|}
\hline Bentic foraminifera & KRAS-1 $\mathrm{F}$ & KRAS-2 $\mathrm{H}$ & KRAS-3 r & KRAS-4 H & KRAS-5 I & KRAS-6 F & KRAS-7 H & KRAS-8 I & KRAS-9 & KRAS-10 & KRAS-11 & KRAS-12 \\
\hline Pullenia bulloides (d'Orbigny) & & 0.4 & 1.8 & 0.5 & 1.9 & 0.5 & 0.5 & 0.5 & & & 0.8 & \\
\hline Quinqueloculina hauerina (d'Orbigny) & & & & & 0.5 & & & & & & & \\
\hline Reussella spinulosa (Reuss) & & 0.9 & & 1.4 & & & & & & & & \\
\hline Rosalina sp. (cf. semiporata) & 2 & 0.9 & 0.9 & & & 0.5 & 1 & 1 & & 1.4 & & \\
\hline Siphonina reticulata (Czjzek) & 0.5 & & & & & 0.5 & 0.5 & 1 & & & & \\
\hline Siphonodosaria verneuili (d'Orbigny) & & 1.7 & 1.3 & 1.4 & & & & & & & & \\
\hline Spirorutilus carinatus (d'Orbigny) & & 0.9 & 0.5 & 1.4 & 1 & & 1.5 & & & & & \\
\hline Stilostomella adolphina (d'Orbigny) & & & & 0.9 & & & & & & & & \\
\hline Stilostomella elegans (d'Orbigny) & 1.5 & & & & 2.4 & 0.9 & & 0.5 & 0.5 & 0.7 & & \\
\hline Textularia gramen d'Orbigny & 0.5 & 0.5 & & & & 0.5 & & 0.5 & 2 & 0.7 & 3.2 & 1.3 \\
\hline Trifarina bradyi Cushman & 3 & 3.9 & 1.8 & 2.8 & 1.9 & 1.4 & & & 0.5 & & & 0.6 \\
\hline Uvigerina aculeata d'Orbigny & 0.5 & & & & & & & & & & & \\
\hline Uvigerina acuminata Hosius & & 2.1 & 0.5 & & & & & & & & & \\
\hline Uvigerina macrocarinata & 0.3 & 0.9 & 1.3 & & & & & & & & & \\
\hline $\begin{array}{l}\text { Uvigerina pygmoides Papp \& } \\
\text { Turnovsky }\end{array}$ & 1 & & & & 0.5 & 0.5 & 1 & 1 & 3 & 1.3 & 1.6 & 1.3 \\
\hline Foraminiferal number & 591 & 699 & 1398 & 1266 & 1680 & 651 & 351.4 & 157.5 & 301.5 & 74 & 63.5 & 78 \\
\hline Number of species & 30 & 33 & 31 & 31 & 32 & 32 & 26 & 25 & 24 & 18 & 19 & 15 \\
\hline Planctonic foraminifers & KRAS-1 & KRAS-2 & KRAS-3 & KRAS-4 & 4 KRAS-5 & KRAS-6 & 5 KRAS-7 & KRAS-8 & KRAS-9 & 9KRAS-10 & KRAS-11 & KRAS-12 \\
\hline Turborotalita quinqueloba (Natland) & 8.7 & 17.1 & & & & 21.1 & & 21.5 & 35.3 & $\mathrm{xx}$ & & \\
\hline Globigerina ottnangiensis Rögl & 0.8 & & 13.6 & 10.8 & 7.3 & 9.8 & 8.8 & 12.7 & 2.9 & & & \\
\hline Globigerina praebulloides Blow & 36.5 & 29.9 & 37.3 & 36 & 23.9 & 17.9 & 38.2 & 22.8 & 38.2 & & & \\
\hline Globigerina bulloides d'Orbigny & 6.3 & 6 & 9 & 6.3 & 14.7 & 4.9 & 5.9 & & & & & \\
\hline Globigerina lentiana Rögl & 5.6 & 4.3 & & & & & & & & & & \\
\hline Globigerinoides bisphericus Todd & 2.4 & & & 0.9 & & 1.6 & 5.9 & 1.3 & & $\mathrm{x}$ & & \\
\hline $\begin{array}{l}\text { Globigerinoides quadrilobatus } \\
\text { (d'Orbigny) }\end{array}$ & 0.8 & & 0.9 & & & 0.8 & & & & & & \\
\hline Globigerinoides trilobus (Reuss) & 0.8 & 0.9 & & 0.9 & & 0.8 & 5.9 & 3.8 & 2.9 & & $\mathrm{xx}$ & \\
\hline Orbulina suturalis Bronnimann & 1.6 & 0.9 & & & & & & & & & $\mathrm{x}$ & \\
\hline Globigerinella regularis (d'Orbigny) & 0.9 & 3.4 & 0.9 & 3.6 & 1.8 & 2.4 & & & & & & \\
\hline $\begin{array}{l}\text { Paragloborotalia mayeri (Cushman \& } \\
\text { Ellisor) }\end{array}$ & 28.8 & 29 & 16.4 & 14.4 & 29.4 & 19.5 & 11.8 & 21.5 & 19.1 & & & $\mathrm{x}$ \\
\hline Globorotalia bykovae (Aisenstat) & 7.1 & 8.5 & 21.8 & 27 & 22.9 & 21.1 & 23.5 & 16.5 & 1.5 & $\mathrm{x}$ & & \\
\hline P/B-ratio & 61.1 & 70.3 & 70 & 77.5 & 71.7 & 67.4 & 14.2 & 27.3 & 25.3 & 3.9 & 1.6 & 0.6 \\
\hline Number of species & 13 & 10 & 8 & 9 & 7 & 11 & 8 & 8 & 7 & 3 & 2 & 1 \\
\hline Nannoplankon & KRAS-1 & KRAS-2 & KRAS-3 & KRAS-4 & KRAS-5 & KRAS-6 & KRAS-7 & KRAS-8 & KRAS-9 & 9KRAS-10 & KRAS-11 & KRAS-12 \\
\hline Coccolithus pelagicus & 19.8 & 9.4 & 9.9 & 9 & 12.6 & 10.7 & 6.9 & 5.7 & 8.6 & 3.2 & 4.7 & 8.5 \\
\hline Reticulofenestra minuta & 77.8 & 85.5 & 85 & 86.4 & 80.8 & 83.3 & 86.2 & 85.7 & 78.6 & 88.7 & 84.1 & 84.7 \\
\hline Reticulofenestra excavata & & & 0.5 & & & & & & & & & \\
\hline Reticulofenestra abisecta & & & & & & 0.4 & & & & & 0.9 & \\
\hline Reticulofenestra bisecta & & & & & & 1.2 & & 1.9 & & 4.8 & 1.9 & 5 \\
\hline Reticulofenestra umbilica & & & & & & 0.4 & & & & & & \\
\hline Cyclicargolithus floridanus & & & & & 2 & & & & 4.3 & & 1.9 & \\
\hline Helicosphaera carteri & 0.6 & 1.7 & 1.4 & & 0.5 & 0.8 & 0.9 & 1 & & & & \\
\hline Helicosphaera walbersdorfensis & 1.2 & 1.3 & 1.4 & 2 & 3.5 & 1.6 & & & & 3.2 & 0.9 & 1.7 \\
\hline Helicosphaera euhratis & & & & & & 0.4 & & & & & & \\
\hline Syracosphaera pulchra & 0.6 & 1.7 & 1.4 & 2 & & 1.2 & & & & & & \\
\hline Sphenolithus moriformis & & & & & 0.5 & & & & & & & \\
\hline Pontosphaera multipora & & & 0.7 & & & & & & & & & \\
\hline Thoracosphaera sp. & & 0.4 & & & & & 6 & 5.7 & 7.1 & & 4.7 & \\
\hline Watzenauria sp. & & & & & & & & & 1.4 & & & \\
\hline large reticulofenestry & & & & 0.4 & & & & & & & 0.9 & \\
\hline $\begin{array}{l}\text { Abundance (number of } \\
\text { species/visual field of microscope) }\end{array}$ & 4 & 5.1 & 3.2 & 8.7 & 5.8 & 7.3 & 2.2 & 0.9 & 0.8 & 0.6 & 0.6 & 0.6 \\
\hline Number of species & 5 & 6 & 7 & 5 & 6 & 5 & 4 & 4 & 4 & 3 & 6 & 3 \\
\hline
\end{tabular}




\section{Appendix B. Abundance data and specimen counts of Echinodermata, Mollusca, Bryozoa} and other fossils for section Kralice III.

\begin{tabular}{|c|c|c|c|c|c|c|c|c|c|c|c|c|}
\hline Echinodermata & KRAS-1 & KRAS-2 & KRAS-3 & KRAS-4 & KRAS-5 & KRAS-6 & KRAS-7 & KRAS-8 & KRAS-9 & KRAS-10 & KRAS-11 & KRAS-12 \\
\hline Cidaroida indet. & & & & & 6 & 8 & & & 3 & 2 & 2 & 1 \\
\hline Stylocidaris polyacantha & & & & & 13 & 10 & & & 4 & 3 & 8 & \\
\hline Diadematidae indet. & & & & & & 2 & 2 & & 9 & 16 & & 2 \\
\hline Echinoidea indet. & & & & & & & & & 4 & 14 & 4 & 4 \\
\hline Temnopleuroida juv. indet. & & & & & & & & & 5 & & & \\
\hline Schizechinus sp. & & & & & & & & & 2 & 6 & 7 & 1 \\
\hline Echinolampas? sp. & & & & & & & & & 13 & & & \\
\hline Conolampas sp. & & & & & & & & & 4 & 1 & & \\
\hline Clypeaster sp. & & & & & & & & & 3 & 3 & 2 & 2 \\
\hline Echinocyamus transylvanicus & & 1 & 1 & & 2 & 1 & 5 & & 22 & 11 & 14 & 2 \\
\hline Spatangoida indet. & 23 & 65 & 95 & 6 & 34 & 71 & 75 & 3 & 297 & 232 & 113 & 130 \\
\hline Spatangus sp. & & 2 & & 2 & 2 & 11 & 19 & 1 & 192 & 136 & 74 & 35 \\
\hline Loveniidae indet. & & 3 & 1 & & & & 2 & & 4 & 1 & & \\
\hline Crinoidea indet. & & & & & & & & & & & 1 & \\
\hline Asteroida indet. & 8 & 10 & 7 & 5 & 36 & 60 & 10 & & 55 & 99 & 42 & 40 \\
\hline Echinoidea total & 23 & 71 & 97 & 8 & 57 & 103 & 103 & 4 & 562 & 425 & 224 & 177 \\
\hline Cummulative & 31 & 81 & 104 & 13 & 93 & 163 & 113 & 4 & 617 & 524 & 267 & 217 \\
\hline Asteroid percentage & 25.8 & 12.4 & 6.7 & 38.5 & 38.7 & 36.8 & 8.9 & 0 & 8.9 & 18.9 & 15.7 & 18.4 \\
\hline Spatangoid percentage & 74.2 & 86.4 & 92.3 & 61.5 & 38.7 & 50.3 & 85 & 100 & 79.9 & 70.4 & 70 & 76 \\
\hline Abundance Sample vs. Total & 1.4 & 3.6 & 4.7 & 0.6 & 4.2 & 7.3 & 5 & 0.2 & 27.7 & 23.5 & 12 & 9.7 \\
\hline
\end{tabular}

semiquantitative abundance (number of specimens), 1 - rare (1-5 sp.), 2- common (6-15 sp.), 3- abundant (16-35 sp.), 4 - very abundant (36-60 sp.), 5 - dominant (over $60 \mathrm{sp}$.)

\begin{tabular}{|c|c|c|c|c|c|c|c|c|c|c|c|c|}
\hline Mollusca & KRAS-1 & KRAS-2 & KRAS-3 & KRAS-4 & KRAS-5 & KRAS-6 & KRAS-7 & KRAS-8 & KRAS & AS-10 & KRAS- & AS-12 \\
\hline $\begin{array}{l}\text { "Chlamys" cf. trilirata (Almera \& } \\
\text { Bofill) }\end{array}$ & & & & & 1 & 1 & & & & & & \\
\hline Aequipecten cf. malvinae (Dubois) & 1 & & & & 1 & & & & & & 2 & 1 \\
\hline $\begin{array}{l}\text { Aequipecten macrotis (Sowerby in } \\
\text { Smith) }\end{array}$ & 1 & 1 & & & 1 & 1 & 1 & & 1 & 2 & 2 & 1 \\
\hline Aequipecten sp. & & & & & & & & & & 3 & 2 & \\
\hline $\begin{array}{l}\text { Costellamussiopecten cristatus badense } \\
\text { (Fontainess) }\end{array}$ & 1 & 3 & 3 & 5 & 5 & 5 & 3 & & 4 & 4 & 4 & 3 \\
\hline $\begin{array}{l}\text { Costellamussiopecten } \mathrm{cf} . \text { spinulosus } \\
\text { (Münster) }\end{array}$ & & & & & & 1 & & & 1 & 1 & 1 & \\
\hline Oopecten cf. solarium (Lamarck) & & & & & 1 & 1 & & & 1 & 2 & 1 & \\
\hline Pectinidae indet. & & & & & & & & & 1 & & 2 & 2 \\
\hline $\begin{array}{l}\text { Neopycnodonte cf. navicularis } \\
\text { (Brocchi) }\end{array}$ & & & & & 1 & & & & & & & \\
\hline Ostrea cf. digitalina (Dubois) & & & & & & 1 & & & 1 & 1 & & \\
\hline Mytilus sp. & & & 1 & & & & & & & & & \\
\hline Bivalvia indet. & 1 & 3 & 4 & 4 & 5 & 5 & 5 & & 5 & 2 & 2 & 2 \\
\hline
\end{tabular}


semiquantitative abundance (number of specimens), 1 - rare (1-5 sp.), 2 - common (6-10 sp.), 3 - abundant (10-20 sp.), 4 - very abundant (20-40 sp.), 5 - dominant (over $40 \mathrm{sp}$.)

\begin{tabular}{|c|c|c|c|c|c|c|c|c|c|c|c|c|}
\hline Bryozoa & KRAS-1 & KRAS-2 & KRAS-3 & KRAS-4 & KRAS-5 & KRAS-6 & 5 KRAS-7 & KRAS- 8 & KRAS-9 & 9KRAS-11 & OKRAS-11 K & KRAS-12 \\
\hline Adeonella polystomella & & & & & & & 1 & & 2 & 1 & 2 & 2 \\
\hline Amphiblestrum appendiculatum & & & & & & & & & & & 1 & \\
\hline Bicrisina compressa & & & & & & & & & & & 1 & \\
\hline Bufoneloides incisa & & 1 & & & & & 2 & & 1 & 2 & 2 & \\
\hline Callopora bobiesi & & & & & & & & & 1 & & & 1 \\
\hline Cellaria fistulosa & & & 1 & & & & 1 & & & & 1 & \\
\hline Cellepora? & & & 2 & 1 & 1 & & & & & 3 & 2 & 1 \\
\hline Celleporina costazi & & & & & & & & & 4 & 3 & 3 & \\
\hline Crisia eburnea & & & & & & & 1 & & & & & \\
\hline Crisia hoernesi & 1 & 1 & & & & & & & & 1 & 1 & 1 \\
\hline Disporella grignonensis & & & & & & & & & & & 1 & \\
\hline Disporella hispida & & & & & & & 1 & & & 1 & 1 & \\
\hline Exidmonea atlantica & & & & & & & & & 1 & & 1 & 2 \\
\hline Exidmonea disticha & & & & & & & & & & & 1 & \\
\hline Frondipora verrucosa & & & & & & & 1 & & & & 1 & \\
\hline Herentia hyndmanii & & & & & & & 1 & & & & & \\
\hline Hippopleurifera semicristata & & & & & & & & & & & 2 & 1 \\
\hline Hippoporella pauper & & & & & & & & & & & 1 & \\
\hline Hornera frondiculata & 1 & & & & & & 1 & & & 1 & 2 & 2 \\
\hline Hornera verrucosa & & & & & & & & & & & 1 & \\
\hline Kionidella moravicensis & & & & & & & 1 & & 1 & & & \\
\hline Mecynoecia pulchella & & & & & & & 2 & & 1 & & 2 & \\
\hline Metrarabdotos mallecki & 1 & 1 & & & & & & & & & 1 & \\
\hline Oncousoecia biloba & & & & & & & & & & 1 & 1 & \\
\hline Onychocella angulosa & & & & & & & & 1 & 3 & 2 & 2 & \\
\hline Phoceana tubulifera & & 1 & & & & & 1 & 1 & 2 & 2 & 2 & \\
\hline Polyascosoecia coronopus & & & & & & & & & & 1 & 1 & \\
\hline Pseudofrondipora foramninosa & & & & & & & & & & & 1 & \\
\hline Pyriporella loxopora & & & & & & & & 1 & 1 & 2 & 2 & \\
\hline Reteporella beaniana & & & 1 & & & & & & & & & \\
\hline Reteporella kralicensis & & 1 & 1 & & & & & & & & & \\
\hline Reteporella septemtrionalis & & 3 & 3 & & & & & & 3 & 1 & 2 & \\
\hline Reteporella sp. & & 2 & & & & & 2 & & 2 & 3 & 3 & 3 \\
\hline Schizoporella geminipora & & 2 & 1 & & & & 3 & 3 & 5 & 5 & 5 & 3 \\
\hline Smittina cervicornis & & 1 & & & & & 4 & 1 & 2 & 2 & 4 & 2 \\
\hline Steginoporella cucullata & & & & & & & & & 2 & 2 & 1 & \\
\hline Tervia irregularis & & 1 & & & & & 2 & & & & 2 & 1 \\
\hline Turbicellepora coronopus & & & & & & & & & 1 & & & \\
\hline Umbonula macrocheila & & 3 & & & & & & & & 1 & & \\
\hline Umbonula spinosa & & 1 & & & & & 2 & 1 & 1 & 2 & 2 & \\
\hline Vibracella trapezoidea & & & & & & & & 1 & 1 & 1 & 2 & 2 \\
\hline Ybselosoecia typica & & & & & & & 1 & 2 & & 1 & 1 & \\
\hline Number of species & 3 & 11 & 5 & 1 & 1 & 0 & 17 & 8 & 18 & 20 & 34 & 11 \\
\hline
\end{tabular}

semiquantitative abundance (number of specimens), 1 - rare (1-5 sp.), 2 - common (6-15 sp.), 3 - abundant (16-35 sp.), 4 - very abundant (36-60 sp.), 5 - dominant (over $60 \mathrm{sp}$.)

\begin{tabular}{|c|c|c|c|c|c|c|c|c|c|c|c|c|}
\hline Other fossil content & KRAS-1 & KRAS-2 & KRAS-3 & KRAS-4 & KRAS-5 & KRAS-6 & KRAS-7 & KRAS-8 & KRAS & -9KRAS- & -10KRAS- & 11 KRAS-12 \\
\hline Polyplacophora & & 1 & 1 & & 1 & 1 & 1 & & & & 1 & \\
\hline Cirripedia & & & & & & 1 & 1 & & & & 1 & \\
\hline Brachiopoda & & 1 & & & 1 & & 1 & & 1 & 1 & 1 & 1 \\
\hline Rhodophyta & & & & 5 & & & 4 & 3 & 5 & & 2 & 2 \\
\hline
\end{tabular}

